\title{
For THE SAKE OF DeBt MANAGEMENT: HOW WAS PRESIDENTIAL DECREE No. 39/1991 DRAFTED?
}

\author{
The Editors
}

On September 4, 1991, President Soeharto issued Presidential Decree No. 39/1991, announcing the formation of the Team for the Coordination of Management of Offshore Commercial Loans (Tim Koordinasi Pengelolaan Pinjaman Komersial Luar Negeri, or Tim PKLN). It consisted of ten ministers and the governor of the Bank of Indonesia and was headed by Coordinating Minister for Economy, Finance, Industry, and Development Supervision, Radius Prawiro. The Team was to coordinate the management of all offshore commercial loans outside the framework of the IGGI and other official loans, to determine the total amount of offshore commercial loans to be procured from the international capital market in each fiscal year, and to decide the priority order of offshore commercial loans for financing development projects and other purposes. ${ }^{1}$ In short, the team was created for debt management to bring expanding offshore commercial loans under control.

About a month later, on October 12, 1991, after the Team met with Soeharto, Coordinating Minister Radius Prawiro announced that it had set ceilings for offshore commercial borrowing by the Bank of Indonesia, state banks, private banks, state corporations, and private corporations, and that it had decided to approve three out of the seven large projects already in the pipeline for implementation in the 1991/92 fiscal year. The projects approved were: LNG Train-F (expansion of the liquidified natural gas complex in Bontang, $\$ 750$ million); an oil refinery in Musi ( $\$ 324.4$ million); and a pipeline to carry gas from a field off Bali to a power station in Gresik, East Java ( $\$ 440$ million). The Aromatics Center II in Arun, Aceh ( $\$ 1.3$ billion), Chandra Asri olefins complex in West Java ( $\$ 2.4$ billion), Exor IV in Dumai (export-oriented oil refinery, $\$ 3.6$ billion), and a residual catalytic converter plant in Cilacap (Residue Conversion Complex [RCC], $\$ 2.5$ billion) were postponed indefinitely. ${ }^{2}$

\footnotetext{
${ }^{1}$ For more on Presidential Decree No. 39/1991, see the complete text included below.

2 For more on Radius' announcement, see "Pemerintah umumkan: Perkiraan pinjaman komersial luar negeri 1991/1992-1995/1996," Business News, October 14, 1991 included below.
} 
The decision, the first of its kind since 1983 when a drop in world oil prices forced the Indonesian government to shelve many projects, was seen as a major victory for the "technocrats" and was applauded by "economists." "Technocrats won," the Jakartan weekly Editor reported. ${ }^{3}$ Asian Wall Street Journal correspondent Richard Borsuk wrote: "With the decision to postpone the olefins plant, 'the technocrats are looking good,' a foreign economist said." 4 Adam Schwarz of the Far Eastern Economic Review also reported: "Indonesia's economic ministers warmed the hearts of many economists and foreign investors by slamming the brakes on overseas borrowings." 5 Though the hearts of foreign inverstors with stakes in the postponed projects were certainly not warmed, there is certainly a strong basis for this assessment, as the "technocrats" had gone further than generally expected and decided to shelve big Pertamina-related petro-chemical projects in which Soeharto's most powerful cronies and children were involved.

The Arun Aromatics Center II project was originally conceived as a private project by $\mathrm{P}$. T. Humpus Aromatics, headed by Soeharto's third son, Tommy Suharto, with its foreign partners, Thyssen A.G. of Germany and M. W. Kellogg of the United States. ${ }^{6}$ But problems arose when Pertamina refused to guarantee the feedstock supply for the facility. Humpus, then, bowed out of direct participation in the project last year and handed the whole project over to Pertamina, which awarded the construction work to a consortium of Thyssen, Chiyoda Corp., and Mitsui \& Co., while Humpus was to serve as a major equipment supplier for the project.

The Exor IV, an oil refinery project in Dumai, Central Sumatra, was planned by Pertamina to boost its exports of refined products. The cost and likely participants changed several times. Pertamina had reportedly been negotiating with several Japanese companies for its construction and financing, and the Salim group, headed by Liem Sioe Liong and his son, Anthony Salim, was involved in the project. Prajogo Pangestu, head of the lumber and plywood giant Barito Pacific and known for his close ties to Soeharto's daughter, Siti Hardiyanti Rukmana, was involved as a probable partner of Pertamina in the RCC project to upgrade an existing refinery at Cilacap and to construct a residual catalytic cracking unit. It was to be constructed by Toyo Engineering Corporation of Japan.

And the most controversial olefins complex project was sponsored by Chandra Asri, owned by Prajogo Pangestu and Henry Pribadi. The project had supplanted an earlier joint project planned by the Royal Dutch/Shell Group and the Bimantara group headed by Soeharto's second son, Bambang Trihatmodjo. Last year, Chandra Asri awarded a construction contract to Toyo Engineering Corporation of Japan and $\mathrm{AB}$ Lummus Crest Inc. of the United States for the project. It was to be financed by a syndicate of local banks led by stateowned Bank Bumi Daya, and a $\$ 500-550$ million irrevocable letter of credit (out of $\$ 1.8$ billion committed by the syndicate) had been issued by Bank Bumi Daya, along with a bank loan of around $\$ 200$ million extended by Bank Bumi Daya and another state bank, Bank

\footnotetext{
${ }^{3}$ Marahsakti, "Menunda Proyek Mega: Tiga proyek raksasa Pertamina ditunda," Editor, October 19, 1991.

4 Richard Borsuk, "Indonesia Postpones Investments in Bid to Limit Imports, Borrowing," The Asian Wall Street Journal Weekly, October 21, 1991.

${ }^{5}$ Adam Schwarz, "Hold the applause," Far Eastern Economic Review, November 7, 1991.

${ }^{6}$ The following description of the projects are based on "Yang; Lolos Hanya Tiga," Tempo, October 19, 1991;

"Menunda Proyek Meda," Editor, October 19, 1991; Richard Borsuk, "Indonesia Postpones Investments in Bid to Limit Imports, Borrowings," The Asian Wall Street Journal Weekly, October 21, 1991; Carl Goldstein, "Crack in the Pipeline," and Adam Schwarz, "Hold the applause," both in the Far Eastern Economic Review, November 7, 1991.
} 
Dagang Negara. Bambang and Peter Gontha of the Bimantara group reportedly also had personal stakes in Chandra Asri.

Clearly the stakes were very high for those whose projects were threatened, and the decision demonstrated that "technocrats" had indeed prevailed over powerful "private" interests. But this does not mean that Soeharto's cronies and children are now out in the cold. The North Bali Pipeline project will be implemented by Bimantara, together with Atlantic Richfield Bali North Inc. and British Petroleum. Bimantara also has the right to manage the facility for twenty years through the P. T. Trans Java Pipeline. The primary contractor for the LNG project is P. T. Inti Karya Persada Teknik, whose major shareholders are Wijaya Karya and two protégés of another of Soeharto's close associates, Bob Hasan -Nusamba and Parama Matra Widya.

Nor are those close to Soeharto shut out of the future big projects approved by the Team. Bambang Suharto's Bimantara is involved in the two projects approved for implementation in 1992/93; Tommy Suharto's Humpus, Siti Hardiyanti's Rukmana, Liem Sioe Liong's Indocument, and Bimantara àre involved in projects for 1993/94; and Bimantara will be a major player in three out of the four projects approved for 1994/95.

This suggests that indeed "President Suharto studied the problem very carefully," as Radius reportedly said, ${ }^{7}$ and decided that some of his friends' and relatives' short-term interests should be sacrificed in order to keep Indonesia from becoming a Southeast Asian Brazil. The principal loser was Pertamina, not only because some of its major projects were indefinitely postponed, but also because its projects, which apparently had never been under any effective supervision by the Ministry of Finance and the coordinating minister, were made subject to approval by the Team headed by Coordinating Minister Radius.

Then, who won? There is no reason to doubt that "Indonesia's technocrats still carry weight with the president." 8 But, as the documents below demonstrate, they were supported by constant heavy doses of foreign advice and the sheer weight of the World Bank. This hidden role of the World Bank advisory group in the decision-making process was only very obliquely reported..$^{9}$ But the foreign economist interviewed by Richard Borsuk must have had a very good reason to be satisfied with the decision.

The documents included below are as follows:

1. The Advisory Group to Coordinating Minister Radius Prawiro, Minister J. B. Sumarlin, Minister Saleh Afiff, Governor Adrianus Mooy, Prof. Widjojo Nitisastro, and Prof. Dr. Ali Wardhana, Memorandum Re: Excessive External Borrowing, Strictly Confidential, January 21, 1991.

2. The Advisory Group to Professor Widjojo Nitisastro, Memorandum Re: The potentially disturbing consequences of excessive borrowing by Indonesian entities in the external commercial financial markets, May 22, 1991.

3. The Advisory Group to Coordinating Minister Radius Prawiro, Minister J. B. Sumarlin, Minister Saleh Afiff, Governor Adrianus Mooy, Prof. Widjojo Nitisastro, and Prof. Dr. Ali Wardhana, Memorandum Re: Debt coordination, May 23, 1991.

\footnotetext{
7 Adam Schwarz and Jonathan Friedland, "Growth on Hold," Far Eastern Economic Review, October 24, 1991.

${ }^{8}$ Borsuk, "Indonesia Postpones Investments."

${ }^{9}$ Only Tempo reported: "World Bank President Lewis Preston agrees and praises the extreme step taken by Indonesia,' he [Finance Minister Sumarlin] said." Mohamad Cholid dan Biro Jakarta, "Yang Lolos Hanya Tiga," Tempo, October 19, 1991.
} 
4. The Advisory Group, Criteria for decision making on rephasing projects, June 6, 1991.

5. The Advisory Group to Coordinating Minister Radius Prawiro and Governor Adrianus Mooy, Memorandum, July 5, 1991.

6. The Advisory Group to Coordinating Minister Radius Prawiro, Minister J. B. Sumarlin, Governor Adrianus Mooy, Minister Saleh Afiff, Prof. Widjojo Nitisastro, and Prof. Dr. Ali Wardhana, Memorandum Re: Ordering of State Project Financing, July 5, 1991.

7. The Advisory Group to Dr. Irzan Tandjung, Assistant to the Minister for Monetary Affairs, Balance of Payments and Public Finance, EKUIN, Memorandum Re: Background to Project Review, July 8, 1991.

8. The Advisory Group to Coordinating Minister Radius Prawiro and Governor Adrianus Mooy, Memorandum Re: Possible Draft Framework for a Press Release, July 8, 1991.

9. The Advisory Group to Coordinating Minister Radius Prawiro, Minister of Finance J. B. Sumarlin, and Governor Adrianus Mooy, Memorandum Re: Project Coordination/Arun Aromatics Project, July 17, 1991.

10. The Advisory Group to Coordinating Minister Radius Prawiro, Minister of Finance J.B. Sumarlin, and Governor Adrianus Mooy, Memorandum Re: Project Coordination/Java Pipeline Project, July 23, 1991.

11. The Advisory Group to Coordinating Minister Radius Prawiro, Minister of Finance J. B. Sumarlin, Governor Adrianus Mooy, Minister Saleh Afiff, Prof. Widjojo Nitisastro, and Prof. Dr. Ali Wardhana, Memorandum Re: Establishment of a maximum borrowing ceiling from the commercial markets for Indonesian borrowers for FY 1991/92, August 30, 1991.

12. The Coordination of Management of Offshore Commercial Loans (Presidential Decree No. 39/1991 dated September 4, 1991).

Postscript: The government gave the most controversial project, Prajogo Pangestu's Chandra Asri olefins complex project, permission to go ahead in April 1992, after its status was changed from domestic to a 100-percent foreign capital investment project and the Bank Bumi Daya's commitment to the project was scrapped. ${ }^{10}$

Further documents bearing on implementation of the decisions will be included in our next issue, Indonesia 55 (April 1993).

${ }^{10}$ For more on this coup, see Tempo, April 25, 1992, pp. 85-93. 
Offshore Loans 153

\section{Document 1}

Strictly Confidential

21st January, 1991

\section{Memorandum}

To: $\quad$ H.E. Coordinating Minister Radius Prawiro

H.E. Minister J. B. Sumarlin

H.E. Minister Saleh Afiff

H.E. Governor Adrianus Mooy

Professor Widjojo Nitisastro

Prof. Dr. Ali Wardhana

From: The Advisory Group

Re: Excessive External Borrowing

\section{Taking into account the following:}

- the probable decrease in the price of oil once the Gulf crisis has been settled;

- the declining rate of growth of non-oil exports, which are lower than expected in FY 90/91, reflecting recessionary trends in the United States and other countries and the prospect of a slowdown in other key economies;

- the change in banking markets in Japan and the United States, which has already given rise to a contraction of liquidity in capital markets worldwide;

- the important short-term component (approximately US\$10 billion at present) of Indonesia's external debt, reflecting the recent high levels of bank financings and private sector borrowings (see schedules already distributed during our recent meetings);

- the limited amount of liquid medium term reserves, after taking into account the swap and gold components of the reserves;

- the freedom given to state and private sector borrowers, whether in banking or manufacturing, to borrow in foreign currencies;

- the substantial overall external debt of the Republic (US\$ 64 billion) including an approximate figure for private sector debt which may well be underestimated;

- the multitude of large projects undertaken or contemplated in many sectors of the economy, which total at present an estimated US\$ 63 billion according to the Advisory Group's project list; and

- the rising concern amongst overseas financial authorities and lenders that Indonesian borrowing is becoming increasingly uncoordinated and excessive.

We believe that:

- deregulation should not be confused with absence of control and supervision particularly in respect of foreign activities. If a policy is pursued of letting the market (i.e., foreign lenders) exercise financial discipline, restraint will be imposed too late, with damaging effects on the country's capacity to renew foreign exchange facilities and maintain sufficiently high levels of reserves. It would in extremis lead to the need to reschedule foreign indebtedness.

- deregulation does not remove the foreign exchange constraints or the need to limit the debt service ratio (which is understated to the extent that it applies only to public borrowings).

- deregulation necessitates an improved system of statistics and information gathering, covering in particular the private sector, and requires that this be vigorously enforced. 


\section{We suggest the following:}

- having regard to the policy which has been pursued with great success to stimulate private enterprise (resulting in a rising level of external borrowings by the private sector), the Government's borrowings are therefore residual and accordingly the Government should control all public sector external financing, i.e.:

i) foreign borrowings including limited recourse financing by state enterprises, in particular those with large investment programmes, for example Pertamina, Perumtel and Garuda; and

ii) external funding of the state banks;

through the introduction of a queue system, thus setting priorities for access by public sector entities (both corporates and banks) to foreign capital markets;

- in addition the foreign borrowing activities of the private banks have to be monitored and taken into account in the operation of a queue system;

- 'administrative guidance' might be given to banks, whether public or private, on their foreign borrowing activities;

- high priority should be given to increasing the level of official external reserves in Bank Indonesia through raising the absolute level of reserves and improving their liquidity, for example, by establishing swap lines utilising the gold reserves as collateral;

- the maintenance of freedom of exchange control which has been one of the principal elements of Indonesia's economic success story brings with it, particularly in a deregulated environment with rising claims by the private sector on foreign exchange reserves, the need to contain the total indebtedness of the country in line with its future debt service capacity. This will have to be achieved through various means, including tight fiscal and monetary policies;

- acceleration of the improvement in bank supervision particularly as regards: (a) capital adequacy; (b) the approved level of net open foreign exchange positions; (c) large lending exposures to specific sectors (for example, real estate and single categories of clients); and (d) last, but not least, licensing policy (quality of management, foreign exchange licences etc.);

- supply of better information to the financial authorities about the purpose for which foreign borrowing (directly or indirectly through the state and private banking system) is incurred; and

- an assessment of the present state of projects in view of a possible deferral. 


\section{Document 2}

22nd May, 1991

\section{Memorandum}

\section{To: $\quad$ Professor Widjojo Nitisastro}

copies to: H.E. Coordinating Minister Radius Prawiro

H.E. Minister J. B. Sumarlin

H.E. Minister Saleh Afiff

H.E. Governor Adrianus Mooy

From: $\quad$ The Advisory Group

Re: The potentially disturbing consequences of excessive borrowing by Indonesian entities in the external commercial financial markets

Over the past three years, the Advisory Group has cautioned the Indonesian authorities on the need for an improved system of coordination and control of the external borrowing activities of Indonesian entitles. (Our last paper on this topic, dated 21st January, 1991, is attached for ease of reference). Concern has repeatedly been expressed to us on this subject from both official and commercial lenders, particularly in view of the magnitude of external financings completed by Indonesian state-owned and private borrowers in the past 16 months.

The table below sets out the volume of Indonesian external commercial borrowings by sector since 1988. The figures for 1991 include the "overhang" of projects announced but not yet financed, of which the market is therefore aware:

\begin{tabular}{lcrrr}
\hline \hline Sector & 1988 & 1989 & 1990 & $1991^{*}$ \\
\hline \multicolumn{5}{c}{ (U.S.\$ million) } \\
State corporate & 316 & - & 1,750 & $8,475^{\mathrm{i}}$ \\
State bank & 140 & 50 & 1,400 & 545 \\
Private corporate & 341 & $1,696^{\mathrm{ii}}$ & 2,737 & 1,138 \\
Private bank & - & 35 & 968 & 349 \\
Sovereign & 856 & 858 & 400 & - \\
Total & 1,653 & 2,649 & 7,255 & 10,507 \\
\hline * until 12th May, 1991. \\
i Including "private sector" projects with significant state corporate in- \\
volvement. (Set out in the attached annex is a breakdown of the state \\
corporate financings in 1991.) \\
ii Includes Freeport Indonesia, amounting to US\$ 550 million. \\
Source: Euromoney.
\end{tabular}

It is evident from the above data that, following the deregulation of October 1988 and May 1989, the total level of external borrowings increased substantially. In 1989 an increase of over $60 \%$ to US\$ 1.6 billion was registered in external commercial borrowing by Indonesian entities; this level grew almost three-fold in 1990 to US $\$ 7.3$ billion and, including projects announced, the level is estimated already to have more than doubled again in the first five months of 1991.

An analysis by category of borrower demonstrates the growing importance of state bank and state corporate external commercial borrowing activities. In 1990 state banks and state corporates accounted for $43 \%$ of total borrowings by Indonesian entities; this level increased to $86 \%$ in the first five months of 1991, including projects announced. Furthermore, closer analysis of the data indicates 


\section{The Editors}

that it is only a handful of Indonesian state banks and corporations that are the most active borrowers in the external financial markets.

We believe that by controlling this comparatively small number of borrowers, the Republic should be able to control a substantial portion of the commercial bank debt which is currently being incurred, at greatly increased cost and significantly shorter maturities. It is not the private sector, but Pertamina, the state banks, and, in the future, Garuda and PLN, which are the key to effective management of Indonesia's commercial debt.

We recognise that the increased level of borrowing activity also reflects the financial deregulation policies implemented so successfully in recent years and is indicative of the expansion of the Indonesian economy. Furthermore, the level of external borrowings has also been heightened by the tight domestic monetary policy of the past year. Nevertheless, continued excessive and unrestrained borrowing on such a scale by Indonesian entities has potentially serious consequences for the Republic in terms of, inter alia, the impact on the balance of payments, the debt service ratio and the overall availability of external financing for Indonesia as a whole.

We are particularly concerned that this borrowing is taking place at a time of generally tightening global liquidity. Financial institutions in a number of countries, including Japan, the predominant commercial lender to Indonesia, have been closely reviewing their capital adequacy ratios, in the light of the BIS targets. Furthermore there have been new and increasing demands for funds worldwide, including from other regional borrowers, for example Korea, as well as from Eastern Europe and the Middle East. This situation has already led to a general rise in financing costs for most borrowers.

Unrestrained market approaches are impacting adversely not only on the credit standing of specific Indonesian borrowers, but also on the market standing of the country as a whole. Concern is now being widely expressed in the international financial markets about the quality of the Republic's debt management. For example, there have been several transactions for state banks in which the allin-cost has effectively almost tripled and the maturities substantially shortened in less than a year. Even more disturbing, however, is the absolute level of margin paid on these recent transactions: Bank Bumi Daya has just completed a transaction at a cost of approximately LIBOR plus 1.50 per cent. for one year. The immediate impact of such transactions, which are viewed by the market as essentially state risk, is to raise doubts about the present availability of funds for the Republic itself on acceptable terms.

Meanwhile, the Train F financing, amounting to US\$ 750 million, is currently in syndication in the commercial markets and the US\$650 million Cilacap debottlenecking project has been in pre-syndication since last year, as has the Musi oil refinery, amounting to US\$300 million. There is also talk now of the Chandra Asri olefins project with a debt financing requirement of US\$1.8 billion, and the Cilacap catalytic cracker, amounting to US $\$ 1.7$ billion. Public attention has also been drawn to Exor IV and the Arun paraxylene plant, with an aggregate cost of US $\$ 2.5$ billion, most of which would fall to be financed in the international debt markets. All these examples of Pertamina projects are stretching market capacity and increasing concern is being voiced at the ability of Indonesia's economy to support this number and volume of projects. There is also concern at the lack of prioritisation being accorded to the projects by the Government and of the Republic's failure to respect the clear market principle.

Events in Indonesia appear to be moving down the path followed by Latin America in the period of its debt build-up prior to the reschedulings of the last 10 years. In 1983 three-quarters of Venezuela's commercial bank external debt had been incurred by state enterprises and only a quarter by the central government. State enterprises evaded borrowing restrictions while incurring significant amounts of short-term debt. When extraneous events such as the Mexican rescheduling and the Falklands War damaged confidence in the entire region, state enterprises were unable to replace or repay this debt, thereby plunging the nation into a series of reschedulings, of which the most recent was only concluded last year, eight years after the initial default.

When considering other analogous situations closer to home, we note the dangerous similarities with the Republic of Indonesia's liquidity problems of 1975. As in 1975, many large projects are being 
undertaken at steadily increasing margins. Shorter maturities on borrowings are being accepted (one year or less and margins of $1.5 \%$ or more over LIBOR). There is also growing speculation as to the degree of co-ordination being exercised by the government over state borrowers, particularly Pertamina. These very problems led to a collapse of confidence in Indonesia in 1975. Today there are new factors exacerbating the situation; an increased and growing financing demand from the private sector, coupled with a contraction of worldwide resources. A combination of all these factors has caused an international banker to comment to us that the situation has "shades of 1975." We are concerned that a further deterioration of the market's perception might lead to other, more distressing, analogies with 1975.

An urgent reaction from the authorities, along the lines of the recommendations we made in our January paper on Excessive External Borrowing, is now required to avoid the mounting risks of a financial crisis. We feel that the most immediate action should be to apply strict control to bank borrowing and in parallel to establish as quickly as possible a priority for state related project financings.

ANNEX

\section{State Corporate Financings}

Set out below is the list of state corporate financings for the first five months of 1991, amounting to US\$ 8,475 million

$\begin{array}{ccl}\text { A. (US\$ million) } & \\ 575 & \text { Shell/Olefins } \\ 120 & \text { Aneka Tambang } \\ 750 & \text { LNG Train F } \\ 400 & \text { Chandra Asri/Olefins } \\ \underline{330} & \text { Far East Investment Co./Musi } \\ \underline{\underline{2,175}} & \end{array}$

$\begin{array}{lll}\text { B. } & 1,400 & \text { Chandra Asri } \\ 1,700 & \text { Cilacap Catalytic Cracker } \\ 2,100 & \text { Exor IV } \\ \underline{1,100} & \text { Exor III }\end{array}$

$\underline{8,475}$

The project financings set out in A have either been signed or are in the market at varying stages of syndication; the market is aware that financing for the projects set out in B is currently, or will soon be required. 


\section{Document 3}

23rd May, 1991

Memorandum

To: H.E. Coordinating Minister Radius Prawiro

H.E. Minister J. B. Sumarlin

H.E. Minister Saleh Afiff

H.E. Governor Adrianus Mooy

Professor Widjojo Nitisastro

Prof. Dr. Ali Wardhana

From: The Advisory Group

Re: Debt coordination

\section{Introduction}

The Advisory Group has for a number of years advocated an improved system of coordination and control of the external borrowing activities of Indonesian entities. Concern has repeatedly been expressed to us on this subject from both official and commercial lenders, particularly given the magnitude of external financings completed by Indonesian state-owned and private borrowers in the past 18 months.

We recognise that the increased level of borrowing activity reflects the financial deregulation policies implemented so successfully in recent years and is indicative of the growth and expansion of the Indonesian economy. Furthermore, the level of external borrowings has also been heightened by the tight domestic monetary policy of the past year. Nevertheless, continued excessive and unrestrained borrowing by Indonesian entities has potentially serious consequences for the Republic in terms of, inter alia, the impact on the balance of payments, the debt service ratio and the overall availability of external financing for Indonesia as a whole. it is therefore essential that deregulation is not seen to be a substitute for the proper allocation of scarce resources.

We are aware that the importance of improved debt coordination and control is fully recognised by the Indonesian authorities and we understand from our recent meetings with Minister Sumarlin in Vancouver and with Governor Mooy both there and in Jakarta that a number of steps are being taken to address these problems. Against this background, we have suggested below a number of practical measures which could be considered, together with the steps you are already taking, to improve debt management and control.

For the purpose of our analysis, we have divided Indonesian borrowers into two broad categories: banks and financial institutions on the one hand and corporate entities on the other. We have subdivided each of these categories into private and public entities,

- Banks and financial institutions

- State-owned

- Private

- Companies

- State-owned

- Private

The purpose of our recommendations is to assist the Indonesian authorities in monitoring all external borrowings (except short-term trade debt) by Indonesian entities (public and private) with a view to exercising control or guidance where appropriate over those activities. By monitoring, we mean: 
- being informed on a timely and accurate basis of the absolute amount of Indonesian external borrowings and thus able to foresee their impact on the outstanding debt and the future cash-flows of the country;

- being aware of external borrowings in preparation by state-owned entities so as to be able to exercise "traffic control," to rationalize whenever possible their terms and conditions, i.e., to ensure that there is no discrepancy in the terms achieved by borrowers of a comparable status, at a given time and to be able, if necessary, to curb the volume of future borrowings;

- with regard to the private sector, we recognize that whilst controlling by regulation the indebtedness of the non-bank private entities may, at worst, be undesirable and, at best, present certain practical problems, up-to-date information in this area is important in terms of judging the situation as a whole and private external debt should not be excluded from the co-ordination process.

I BANKS AND FINANCIAL INSTITUTIONS

Following (i) the deregulation measures of October 1988 which eliminated the ceilings on offshore borrowings by Indonesian banks and non-bank financial institutions, (ii) the abolition of Bank Indonesia's subsidized refinancing facilities in January 1990 and (iii) the tight domestic monetary policy implemented in early 1990, Indonesian banks have borrowed heavily internationally, partly to compensate for the lack of domestic liquidity.

In 1988, for example, Indonesian state banks borrowed US $\$ 140$ million in international markets, and private banks did no borrowing in these markets. In 1990, state bank borrowings increased ten-fold, to US\$1.4 billion, and private banks borrowed an additional US\$986 million. This pattern of heavy usage of the international markets has continued into 1991, with approximately US\$ 900 million already raised from the market so far this year.

The analysis of these borrowings shows:

- A substantial aggregate amount which has utilised much of the total Indonesian credit capacity with international commercial banks;

- Deteriorating terms over the period; several banks have borrowed at spreads which have doubled compared with earlier transactions, and at significantly shorter maturities; and

- Inconsistency in the terms and conditions. Costs such as front-end fees and security, if any, attached to a facility, such as collateral or offsetting balances must be taken into account when comparing terms and conditions.

We have already reported to you that one of the main concerns voiced by the international financial community has been the failure on the part of Indonesian borrowers to respect the clear market principle. This disregard for what is commonly accepted market practice has made syndication of certain Indonesian transactions difficult, and such a disorderly approach has had a negative impact on the image of the Republic as a borrower in international financial markets.

Bank Indonesia should state clearly to the banks under its supervision the few fundamental issues with which it is greatly concerned, most importantly;

1. The continuing good image of the Republic as a borrower in the international financial markets, which depends in large measure on the consistency in the terms achieved by relevant Indonesian borrowers; under comparable circumstances, borrowers of a similar creditworthiness should receive similar terms and conditions; and

2. The orderly access to the market which may require market clearance with priority accorded to the Republic's borrowings.

This could be presented by Bank Indonesia as the "rules of the game" comparable to those already laid down by Bank Indonesia in the area of bank supervision.

Monitoring should be presented as a guidance from Bank Indonesia offered to banks, rather than as a control imposed upon these banks. Bank Indonesia should stress to the banks the overall objective of this exercise: the vital need for information in order to monitor the future debt service of the Republic. 


\section{A. STATE BANKS}

We recommend the following measures:

- Information flows should be improved

- General knowledge by Bank Indonesia of state banks' activities

The exchange of information between state banks and Bank Indonesia should be thorough, frequent and detailed. It is our understanding that, in addition to the written reports (weekly and monthly) referred to in the February 1991 regulation package on banking supervision, senior officials from state banks are invited to Bank Indonesia on an individual and regular basis. We would encourage Bank Indonesia i) to increase, if possible, the frequency of such meetings and ii) to take advantage of these meetings to question the management of these banks on their offshore borrowing activities and major foreign financed facilities recently contracted and/or planned, so as to construct a clear picture of likely market impact. State banks should also be kept informed of the terms and conditions of the Republic's recent syndicated loans and bond issues, so that they have a benchmark.

Existing regulations should be enforced in a systematic and precise way. In their reports to Bank Indonesia in which banks are requested to inform Bank Indonesia of their plans for future financing operations, state banks should indicate the terms and conditions (including confidential front-end fees, side agreements, security requested, if any) and the purpose of their borrowings: whether they are for their own consumption, for a corporate client, or for an industrial project; if for a project, the project's expected repayment period should be indicated.

\section{- State banks should share information}

State banks should be encouraged to speak to each other and to share information so that they can organize among themselves an orderly approach to the market as well as a certain consistency in the terms of their various transactions. However, until such time as banks, who will initially consider themselves as potential competitors, organize themselves to go to the market, Bank Indonesia has to play the coordinating role.

- Approach to the market should be coordinated

We feel market clearance/traffic control is of fundamental importance and it should be clearly understood that sanctions will be imposed by Bank Indonesia if its guidance and control are not respected.

- Timing

On an informal basis, Bank Indonesia should be able to establish among the state banks a calendar for their forthcoming borrowings.

Before confirming the timing of a borrowing, state banks should call Bank Indonesia:

- to let Bank Indonesia know that they are ready to proceed; and

- to check that the date anticipated for their operation does not conflict with other existing operations which are ready to be launched or which are currently in syndication.

In the event of a potential timing conflict, Bank Indonesia should allocate priorities, if necessary by means of a queuing system.

\section{- Mandate}

No state bank should be allowed to give more than one financing mandate at the same time. Banks we visited in the region have reported to us that on several occasions they had been approached by two mandated banks at the same time for two different transactions by the same Indonesian bank borrower on terms which were not consistent. On an occasion three mandated banks were involved. 


\section{- Comparable terms should be achieved}

Before granting a mandate for a transaction, state banks should obtain agreement from Bank Indonesia that the terms and conditions negotiated with the arranging bank are consistent with the most recent transactions of other state banks. Ideally, they should also make sure that their transaction is better priced than the most recent transactions of Indonesian private banks. This can be done in an informal and confidential manner with Bank Indonesia.

- Appropriate resources should be allocated at Bank Indonesia

- Analysis of information

An officer at senior level at Bank Indonesia, ideally at managing director level, should be responsible for monitoring state banks' borrowing activities abroad. A team comprising two to three persons could be established to implement the above mentioned recommendations; this team would be in charge of i) gathering market intelligence and information on transactions by Indonesian banks, both state and private; ii) centralizing this information; iii) comparing the terms and conditions obtained; and iv) organizing "traffic control" among state banks in order to coordinate their access to the market.

- Training

We understand guidance is already offered by Bank Indonesia in the form of training to all state bank personnel. Guidelines of sound financing practice should be issued to all banks and, whenever feasible, seminars organized under the auspices of Bank Indonesia.

\section{B. PRIVATE BANKS}

While it may be more difficult in practice for Bank Indonesia to follow private banks' activities than those of state banks, there is every reason in principle why the same exchange of supplementary information beyond that mentioned in the recent banking supervision package should be required so that the private foreign exchange banks come to Bank Indonesia for market clearance and for guidance on the terms and conditions of an international financing operation prior to granting a mandate. While Indonesia's credit as such is not as directly implicated by the access of private banks to the market, nevertheless, in the absence of such equality of treatment there could arise a permanent shift of overseas borrowing business from the state banks.

Following the deregulation of the banking sector a great number of private foreign exchange banks have flourished; the sheer number of these banks makes it more difficult for Bank Indonesia to know their management well and to meet with their management on a regular and frequent basis. We understand that the reporting requirements included in the February 1991 package apply equally to state and private banks. We also understand that Bank Indonesia meets regularly with the management of the private banks but on a collective, not on a one to one, basis.

As with state banks, Bank Indonesia should invite on an individual and regular basis, the relevant directors of all private banks borrowing offshore to discuss their business and operations and in particular, their offshore borrowing activities. Bank Indonesia should advise private banks to approach Bank Indonesia on a confidential and informal basis prior to entering the market.

Bank Indonesia should ensure that the regulatory reporting requirements are met in a timely and accurate fashion by the private banks.

II COMPANIES

A. PUBLIC SECTOR BORROWING

Foreign exchange borrowings from the public sector can be classified in several ways including:

- by debt categories,

- by borrower.

- By debt categories 
Multilateral debt is relatively easy to monitor. It is essentially debt contracted by public entities except for the limited number of loans from multilateral agencies such as the IFC or the ADB to private sector borrowers.

- Bilateral debt

Whether for public or private sector borrowers, bilateral debt is also easy to monitor on an historical basis. It is easy to identify and to reconcile with creditors.

It is fair to say that bilateral creditors prefer to lend to public sector borrowers or to private or semi-public borrowers with the sovereign guarantee. In Indonesia, the Republic does not give its formal repayment guarantee to foreign currency borrowings from private or semi-public entities.

However, some export credit agencies do guarantee loans to privately sponsored projects, including some financed on a limited recourse basis, and hence one cannot assume bilateral debt is exclusively contracted with public sector borrowers.

Again, however, bilateral debt is relatively easy to identify, to record and reconcile by creditor, borrower and project.

- Commercial bank debt/Trade debt

Commercial bank debt is the most difficult debt category to monitor, since it is diffuse, spread over a great number of creditor banks and no centralized information reporting system is currently available to the Indonesian authorities.

Trade debt is similarly difficult to check; however, it is essentially short-term in nature and its risks are materially less in the present context than the other debt categories being considered.

- By Borrower

State-owned entities

It is our understanding that the indebtedness of public sector companies is under the control of two entities: the Ministry of Finance and Bappenas.

The Ministry of Finance must approve the external indebtedness of state-owned entities, on a case by case basis, before the financial contract can be signed. Bappenas on the macroeconomic level allocates, on a yearly basis, through the mechanism of the Blue Book, a share of the potential overall external public indebtedness to each industrial and economic sector via the respective technical ministries.

By its nature, Bappenas' role concentrates on the planning and analysis of resource allocation on an a priori basis, but does not monitor the loans once the debt has been contracted nor is it interested in the explicit structure of the financing.

However,

- Bappenas' role focuses essentially on the official indebtedness of the Republic contracted from multilateral and bilateral sources; Bappenas does not oversee nor plan public sector projects financed by commercial bank loans;

- Bappenas does not cover all the sectors of the economy. It is our understanding, for example, that oil and gas projects developed by Pertamina are not under Bappenas' coordination;

- Bappenas' coordination does not include all bilateral credits to be contracted by the Republic. Some export credit financings arrive at the Ministry of Finance for approval without having been presented to Bappenas;

- A number of projects are developed outside and in addition to the Blue Book which represents the official list of projects;

We would suggest the following: 
- Bappenas' coordination and planning activity should encompass all sectors of the economy, without exception. Given the magnitude of the oil and gas sectors for instance, and their current adverse impact on the Republic's debt ratios, it is becoming more necessary than ever to centralize all information available on the external borrowings anticipated from every economic field of the public sector.

- Bappenas' coordination and planning activity should also encompass commercial bank debt. With the increasing share of commercial bank debt in the overall external public debt of the Republic, it is becoming more difficult to justify the exclusion of the commercial bank debt from the macroeconomic planning process of the Republic.

A list of all public sector projects and institutions for commercial bank funding should be established in the same fashion as the Bappenas "Blue Book." We would suggest Bappenas should be responsible for this list since it is complementary to the other debt categories. This list should reflect the priorities set for Indonesia's development. Bank Indonesia on behalf of the Republic and state-owned banks, Pertamina for its oil and gas projects and the Ministry of Finance for public sector companies under its authority (including Garuda), should assess their financing needs over the relevant period and the timing and amounts of these needs should be reviewed on a quarterly basis. Ministries would indicate the projects currently under preparation which would require commercial funding over the next three years and would identify the non-guaranteed portion of the foreign exchange share of cost as well as the domestic financing requirement. Priorities should be set. Pertamina may have to establish its own priorities within the total amount of funds allocated to oil and gas projects which will need funding by commercial banks. We would not advise the Republic to let the market decide on which projects will receive financing and which will not, since the priorities of the market are different from the development priorities of the Republic.

The extent of public financings going directly to the Ministry of Finance for approval without having been incorporated in the planning process of Bappenas should be kept to a minimum. We acknowledge the need for some flexibility to be built into the planning of foreign exchange borrowings in cases where, during the year, once the list of external borrowings has been approved, unforeseen and urgent needs appear that need to be funded: e.g. cost overruns for a project, emergency cases, financing offers that are proposed by suppliers or financial institutions during the year. These side-offers, however, have to be kept within the reasonable limit of a pre-established ceiling.

While the Ministry of Finance approves all external financings by state-owned companies, a number of financings arrive at the Ministry of Finance for approval at the final stage of the project's development. Very often, commercial contracts have been signed or are at the point of being signed before negotiations for the financing have taken place. Given the timing of the information provided, it is very difficult for the Ministry of Finance to assess the financial implications of a project, to assess its financial viability, to propose alternative sources of financing or alternative financing structures, or to reject a project which is inadequately financed. The Ministry of Finance thus has little power to discriminate between competing claims on debt market resources. It is also very difficult for the Ministry of Finance to have a view of the overall needs in the year to come and to plan alternative financings or funding schemes on a consolidated basis. This is particularly true for the non-guaranteed portions of export credits.

We would recommend the following:

1. State entities should advise the Ministry of Finance of their plans on a semi-annual basis. They should report their anticipated needs for funds to the Ministry of Finance as early as they can identify them and provide information as soon as possible on

i) projects under preparation,

ii) the status of their negotiation; and 
iii) the expected date at which financing will be needed.

We have attached in Annex I a suggested form that state entities should complete semi-annually.

2. The Ministry of Finance should not approve the financing of a project which has not been previously brought to its attention in accordance with 1 . above;

3. State entities should inform the Ministry of Finance regularly of the status of their negotiations regarding a project and its financing;

4. Adequate time (6 weeks) should be given to the Ministry of Finance to review and where appropriate, approve the terms of a financing proposal (which should contain a formal offer) and any resulting mandate;

5. No commercial contract should be signed before the approval of the Ministry of Finance has been formally given to the financing terms and conditions proposed;

6. The representative of the Ministry of Finance on the Board of Commissioners of state companies should review closely the operations that would entail foreign borrowing and should ensure that these have been properly reported to the Ministry of Finance;

It is our understanding that, in November 1990, state trading companies ("Perseros") which have gone public have been relieved of the obligation to comply with some of the restrictions otherwise applicable to Perseros. They have been allowed to borrow without the prior approval of the Ministry of Finance except in its capacity as shareholder. This change will exacerbate the difficulty of centralized debt management and coordination.

7. The Ministry of Finance should remain extremely cautious on the question of contingent liabilities entered into where a state entity is involved in a project as a shareholder, as a feedstock supplier, as a guarantor, as an end user and/or purchaser of the end product. Pipeline projects developed by Pertamina, for example, are the kind of such projects which require particular attention from the Ministry of Finance.

8. Given the magnitude and the number of Pertamina projects (i.e., projects developed by Pertamina or related to Pertamina), and given the size and the potential impact of their financing, we would urge the Republic to submit Pertamina to the same monitoring system as other state entities. At present, Pertamina projects do not seem to be under the effective supervision of any ministry other than the Ministry of Finance and the Coordinating Minister. However, the stage at which the projects reach the Ministry of Finance makes it impossible for the latter to exercise any monitoring of these projects. Pertamina projects typically arrive at the Ministry of Finance once they have been extensively negotiated with commercial parties and even financing parties. Henceforth we would recommend that Pertamina projects should be part of this overall effort of debt coordination and monitoring.

9. In our reckoning of Indonesian debt, we would include all the existing debt of the country whether contracted on a limited recourse basis or non recourse basis. It is illusory to categorise these two types of debt as other than the indebtedness of the State.

10. The purpose of this analysis is to derive from the information collected from these different sources an estimate for the total amount of debt outstanding and for the total amount of debt service that will be due over the next few years by the Republic. For each project under consideration, an outline financing structure could be drawn up whereby estimates of (i) equity vs loan financing, and (ii) external financing vs domestic portion, would be made. (This is not an accounting exercise and percentages and approximate gross figures can be used.) Once a loan has been contracted, it is then possible to refine the projections. For each borrowing, the terms and condi- 
tions applied to the amount of debt borrowed should allow a repayment schedule to be drawn up.

\section{B. PRIVATE SECTOR}

By definition, private sector borrowings are the most difficult to monitor. So far, it is our understanding that there is no reporting requirement imposed on private companies with respect to their external borrowings. Without deviating from the commitment to a deregulated private sector, however, the Republic may still be able to improve its information on the borrowing activities in this sector.

We would suggest the following routes to the gathering of information:

- $B K P M$

BKPM, as the "one-stop" agency for domestic and foreign investments in Indonesia which grants investment licences and permits, requests information from applicants on their financing plans for future projects.

Information to BKPM is provided in the investment application form, on a project by project basis, whenever an equity investment is considered in Indonesia, whether by a domestic or foreign entity.

However,

- BKPM does not cover all sectors of the economy; the general mining sector, for instance, is not under BKPM's responsibility.

- BKPM does not cover all investments; investment applicants for projects located in a Bonded Zone submit their application directly to the Bonded Zone Authority.

- For the projects followed by BKPM, the information on foreign borrowings requested in the investment application form is limited to one item, the amount of the offshore loan in US\$. This information, even when available, is not sufficient.

- Once the project's implementation has been decided, investors do not report on the implementation of their project nor on the financing raised or to be raised. It seems that for tax reasons, private sector investors are reluctant to share information on their offshore borrowings with the Indonesian authorities.

As a set of practical recommendations, we would suggest the following:

- Use existing BKPM channels of information;

- The investment application forms should be expanded by one section in Part VII Capitalization:

- Loan Financing

For each loan anticipated, the following information should be provided:

Amount
Maturity
Disbursement period
Repayment period
Currency
Interest rate
Fees
Lending Bank

- Enforce a follow-up on each file/project so as to gather information on the financing structure of projects which are being implemented. Information in the same format should be provided to BKPM for each loan contracted.

- Each Bonded Zone Authority should report to BKPM on approved projects. 
- The Ministry of Mines and Energy should, for each investment approved, gather information on external financings anticipated and implemented in its sector, similar to that which BKPM is requesting.

- Technical Ministries/Directorate

At some stage of their development, most private projects typically need support from the Government in the form of infrastructure to be provided to the site of the project, as well as licences, tax exemptions, etc; in such cases, the Government should take the opportunity to gather information and market intelligence on private projects.

It is our understanding that the Ministry of Industry has considerable information on the various projects privately developed which are under preparation or under negotiation. Each department should promptly submit to Bappenas details of any major project which comes to its attention above a minimum cost level to be agreed; we would suggest US\$200 million. Similar reports should be submitted by technical ministries and directorates.

- Press

Press articles from domestic or international newspapers are very often a good source of information on projects under consideration which would entail, if realised, external borrowings.

- Conglomerates

It is our understanding that as a safe assumption, the $20-80 \%$ rule of thumb could be applied so that by speaking to a handful of conglomerates that represent a sizeable portion of the private sector activity, it should be possible to estimate the likely volume of external private borrowings.

By speaking to the managing directors of these 12 to 15 conglomerates, on an informal, individual basis, it would be possible to build up an approximate picture of the amount and profile of foreign exchange borrowings currently outstanding with the private sector.

Information on the external borrowings of these groups could be requested from the conglomerates for each of their subsidiaries.

In conclusion, information would initially be gathered by and concentrated at BKPM, BAPPENAS, the Ministry of Finance and Bank Indonesia.

The above information flows would then need to be checked, cross checked, reconciled, and analysed by the joint debt coordination team so as to constitute a useful tool in the debt coordination efforts of the Republic. The end result of these flows of information should be:

1) debt service projections for each identified borrowing;

2) cash flow projections of net foreign exchange revenues; and

3) aggregate foreign exchange costs to the Republic.

The collection and analysis of the data required will be a time-consuming activity, requiring the attention of a dedicated staff. We have assumed that the joint debt coordination team, comprising representatives of Bank Indonesia, the Ministry of Finance and Bappenas, will have available the relevant personnel. 
PROJECT NAME:

\author{
ANNEXI \\ BLUE BOOK or \\ BKPM \\ $100 \%$ Gov. Owned or \\ $100 \%$ private or \\ joint venture
}

DESCRIPTION:

LOCATION:

ESTIMATE INVESTMENT COST:

- Local component:

- Foreign component:

STATUS: Under Study:

Under Preparation:

Under Construction:

EXPECTED COMPLETION DATE:

SPONSORS/CONTRACTORS:

FINANCING:

- Equity:

- Local component:

- Foreign component:

- Loan:

- Multilateral:

- Bilateral:

- Government to government:

- Export credits:

- Commercial financing:

- Limited recourse financing:

- Other financing arrangements/special features:

INVESTMENT/DISBURSEMENT SCHEDULE

Local portion

Foreign portion

Total

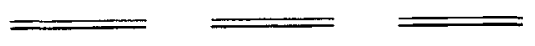




\title{
Document 4
}

\author{
From: The Advisory Group \\ Date: June 6th, 1991 \\ Re.: Criteria for decision making on rephasing projects
}

\begin{abstract}
As requested, we have outlined below some preliminary ideas on the criteria that could be used by the Indonesian authorities in rephasing existing projects. We have also attached a paper prepared by the Advisory Group in 1983, at the time of the last rephasing, setting out the factors which might be taken into consideration when announcing the Republic's decision. In addition, we have attached a copy of a draft letter which was sent to the relevant embassies in Jakarta and export credit agencies explaining the background to and rationale for the previous rephasing. Although it may be premature at this juncture to send out a similar letter, it is important that the reasons for this rephasing are clearly understood by the international financial community. At the appropriate time, therefore, it would be advisable to make an appropriate statement and perhaps send such a letter of explanation.

Investment projects have a wide ranging impact on the Indonesian economy. They should be assessed:
\end{abstract}

- not only from a financial point of view (project cost, impact on the Republic's external debt and foreign exchange balance of payments); but also

- from an economic point of view (micro and macro economic, cost/benefit analysis),

- from a social point of view (income distribution, employment); and

- from a technological point of view.

The criteria to be used by the Indonesian authorities should reflect these various points of view so that the diversity of interests involved in the analysis of a project are taken into account. We have concentrated in our memorandum on financial criteria.

Indonesia currently faces two major constraints, a BOP constraint and a debt/borrowing constraint. As far as the BOP constraint is concerned, a current account deficit of $\$ 4.3$ billion is projected for FY 1991/92. This level, which represents a further deterioration on the deficit of FY 1990/91, should at least not be exceeded; there is a concern that a few capital intensive projects may easily lead to an increase in the current account deficit of several billion dollars. A larger current account deficit may result in i) a loss of confidence in the Republic's capacity to control its external borrowing and ii) capital outflow. In addition, a serious bank exposure problem has emerged as a result of heavy borrowing by Indonesian entities during the last two years, which has all but exhausted commercial banks' lending capacities. This has led to extremely expensive margins and shorter maturities on Indonesian borrowings. As a result, Indonesia's debt structure has deteriorated substantially and has become more vulnerable to external shocks (i.e., oil price fall, credit squeeze, etc). It is very important that borrowing pressures on international markets are reduced in order to preserve some bank exposure capacity for Indonesia and to improve the Republic's debt structure.

We would like to stress that the way in which the rephasing of projects is implemented is of paramount importance to the success of the operation; it is essential that all projects are treated in what appears to be a fair manner and that the objectives of such a rephasing are clearly explained to and understood by the state entities concerned and their foreign partners. The reasons for rephasing and decisions taken in this respect should be communicated directly with the entities concerned. Equally important is the impact on the foreign partners of the state entities. Communication with foreign partners needs to be very carefully handled so as to preserve the future relationship. In their announcement of the rephasing of projects, the Indonesian authorities should stress their commitment to an orderly development program, the fact that priorities had to be set and that in view of scarce financial resources, all projects could not be implemented simultaneously. 
It would be particularly beneficial if an announcement could be made regarding the general direction of Government policy in this respect at the forthcoming IGGI, since as you may be aware, a number of IGGI donors, in particular Japan, have expressed serious concerns regarding the consequences of the very large number of projects under active consideration in Indonesia and have suggested the need to prioritise the projects to a greater extent.

\section{A) PROJECT COVERAGE}

With a view to facilitating the implementation of the rephasing of projects, the Indonesian authorities could limit the scope of their review to:

- Projects of a minimum size: given the magnitude of the rephasing task to be undertaken, we would suggest as a general benchmark that projects with an investment cost of US\$200 million or above, should be reviewed;

- Projects developed by state entities or in which state entities have any kind of involvement or participation, whether in the form of equity for joint-venture projects, offtake, feedstock or supply contracts, or long-term purchase or usage agreements; and

- Projects by state sector entities which are typically considered as off-budget and which are not accounted for in the official record of the external public debt of the Republic including, for example, non-recourse or limited recourse projects, BOO or BOT financing schemes, or lease agreements.

B) CRITERIA

In our opinion and from the financial point of view which is the main focus of the memorandum, three main combined criteria should be considered in the analysis leading to the decision of rephasing:

- the financing structure;

- the foreign exchange pay-back period; and

- the degree of completion.

a) Financing structure

The first candidates for rephasing would be the projects involving a substantial portion of commercial financing rather than those supported by multilateral or bilateral sources of finance;

b) Foreign exchange pay-back period

The projects which will provide the Republic with a net positive foreign exchange cash-flow in the shortest period of time should be given priority;

c) Degree of completion

The status of the project, in terms of its degree of completion, is, in our view, a criterion of prevailing importance.

The costs associated with rephasing projects which have started implementation would be significant both in financial terms and in terms of relationships with foreign suppliers/contractors which have existing contractual commitments from Indonesian public entities. In the first instance, therefore, projects which have not yet started should be considered for rephasing rather than projects which are in the implementation phase, subject, however, to the other criteria mentioned above as well as the wider economic and social implications for the Republic.

For the purpose of our analysis, we have divided the projects into three categories, based on their degree of completion.

- Category 1-Projects which have not started,

- Category 2-Projects which are substantially completed,

- Category 3-Projects in the implementation phase. 
We feel that this is a useful starting point when considering which projects should be rephased, although other factors (as already discussed) will also have to be taken into account.

1. Projects which have not started

- Projects "in the pipeline" i.e., under consideration/being planned, should be suspended first;

- Projects under negotiation should be postponed;

- No letter of intent should be signed at this juncture, including letters of intent being currently negotiated;

- Projects for which no bank has been mandated to raise the financing should be suspended;

- Projects for which there has been no financing raised or committed should be suspended;

Subject to a careful analysis of the impact of construction delays on commercial contracts already signed with long-term buyers of the output:

- Projects for which disbursement of loans has not started can be suspended;

- Projects for which construction has not yet started can be suspended on the basis that projects at the pre-construction stage are easier to rephase than projects already under construction as stated above;

In conclusion, the freeze should affect any further negotiations, signature or commitment by state entities, for all types of projects, except in certain high priority infrastructure areas such as electricity generation, where such a freeze might have too much of an adverse impact on the future economic development of the country.

This freeze should be presented as a temporary one, necessary to let the Indonesian authorities set priorities among the various projects to be developed in Indonesia. The criteria to be applied in evaluating which projects should be suspended or delayed would be the same as those outlined in Section 3.2 below.

2. Projects which are substantially completed

Conversely, projects which are substantially completed, say with 60 to $75 \%$ completion, should in general be allowed to proceed. The cost implied in completing these projects would almost certainly be less than the return of those projects once completed and much less than the cost implied in an unfinished project with outstanding debt incurring financial charges.

3. Projects in the implementation phase.

3.1. Projects which have just started

Projects which have just started (i.e., less than $25 \%$ complete) might also be considered as candidates for rephasing. We would, however, be cautious and would not rephase these projects before having scrutinised all projects mentioned in Section 1 above.

3.2. Projects in the $25-60 \%$ completion range

For projects in the range of $25-60 \%$, priorities will have to be set using the following criteria:

- Given the current Balance of Payments/Debt situation of the Republic, largely and highly capital intensive projects (above $\$ 1$ billion, for instance) should be closely reviewed since they should merit a lower priority. Suspending a few of these highly visible projects would achieve a great deal in terms of sending a signal both domestically and internationally of the Republic's commitment to better control and co-ordination of external borrowing. It would also be valuable in terms of curbing the external liabilities of the Republic;

Given the sheer number of projects that are likely to fall within the $25-60 \%$ completion range, we believe that, as a practical matter, the Indonesian authorities should concentrate on scrutinising the major projects-as was done in the 1983 rephasing exercise. A 
review of a comparatively small number of the largest projects would have a substantial impact on the overall magnitude of the problem.

- Projects with a high import content should be ascribed a lower priority in view of the current Balance of Payments situation of the Republic;

- Conversely, projects which allow maximum net additional foreign exchange earnings with minimum foreign exchange input and a fast realization of such earnings deserve higher priority. Foreign exchange generating projects should be maintained as long as the output is contracted through medium and long-term purchase agreements.

- Medium scale labor intensive projects merit a high priority. This not only fits in with the financial criteria stated above but also with the Republic's social and economic objectives as stated in the Repelita and the President's Speech which stressed the importance of economic growth, the need for social infrastructure, income distribution, and increased employment opportunities;

- Rehabilitation projects and/or production expansion projects, particularly exportoriented projects which require relatively small amounts of investment and produce export earnings relatively quickly, should also be given serious consideration;

- Projects relying heavily on commercial bank fundings deserve a lower priority than projects relying on multilateral funding, including ODA and official export credit finance. It should be noted that so-called "non-recourse financings" also consume banks' exposure to a large extent, sometimes even as much as $100 \%$ of the loan amount. Borrowings by joint-venture companies should also be reviewed, specifically with regard to the actual extent of foreign direct investment; in some cases, the joint-venture companies are simply financing vehicles and the project is principally financed through commercial borrowings and the proportion of equity invested in cash is minimal. We would like to emphasize the importance of not overstraining the financial commercial market which over the last few years has been overwhelmed by borrowings by Indonesian entities; thus, projects relying heavily on commercial bank funding should be suspended prior to projects relying on multilateral funding;

- Conversely, projects relying essentially on multilateral funding as well as projects which are financed by ODA, official export credits and foreign direct investments can be given a higher priority to the extent that they satisfy the development priorities of the Republic and/or ensure a rapid foreign exchange pay back;

- Private foreign direct investment, including investments for the expansion of production capacity of joint venture companies, should be encouraged. This private foreign direct investment should not, however, be conditional upon Government subsidies being provided as an incentive to invest.

We feel that there is scope for a significant rephasing of projects included in the first category outlined above, i.e., projects which have not started yet and that projects in the third category, i.e., which have started implementation, should only be rephased if the impact of the rephasing of projects in the first category is not sufficient.

With regard to projects in the first category, i.e., in the pipeline, once a priority list has been drawn up, based on the set of criteria outlined above in Section 3.2., projects should be implemented depending on the availability of financial resources.

Depending on the preference of the Indonesian authorities, two approaches would be possible:

(i) If the Indonesian Authorities want to adopt an initially quite cautious approach, they could concentrate exclusively on projects in the first category, i.e., in the pipeline. The criteria outlined in Section 3.2. could be applied in reviewing these projects which have not yet started. Projects in category II and III would, for the time being, continue unchanged. It may not be necessary to duplicate what was done in 1983. 
(ii) On the other hand, if the Indonesian Authorities feel that more drastic action is required from the beginning, they could: (a) impose a general "freeze" on all projects which are in the pipeline, (b) then set priorities among projects in category III (i.e., under implementation) and identify those projects which can be rephased, taking into account the criteria outlined in Section 3.2.; and (c) subsequently review the projects in the pipeline which have all been temporarily suspended, in order to identify priorities among this category of projects for such time as it is deemed appropriate to reinstate some of those projects.

C) PROCEDURES

1. Establishment of a priority list among projects.

1.1. Technical ministries and directorates should indicate to the Ministry of Finance or Coordinating Ministry, on a strictly confidential basis, the projects which they feel could be postponed and those which should not be suspended for technical, technological or competitive reasons. Execution ministries should support their reasons for setting such priorities among various projects and should provide supporting data, for instance, economic and financial feasibility studies.

1.2. State entities should submit a comparable list to the Ministry of Finance or Coordinating

1.3. Taking into account the potential impact on the overall development of the Indonesian economy of suspending various projects, Bappenas should also indicate to the Ministry of Finance or Coordinating Ministry, its advice on which projects in which economic sectors could be delayed and which ideally should not. Bappenas' advice will be given from the point of view of planning the overall development of the economy. It will also be given with the view to the absolute level of external debt which is acceptable, taking into account the overall debt service capacity of the country.

Moreover, for each project, Bappenas will need to ascertain whether the necessary infrastructure is currently available. If it is not, the cost associated with providing the necessary infrastructure should be assessed.

1.4. These lists should be reviewed by an independent team (i.e., consisting of representatives of Bank Indonesia, Ministry of Finance, Bappenas and Coordinating Ministry) with access to adequate information. The independent team would merge the data provided from these various sources and produce one master list. The Advisory Group would be available as appropriate to assist the team in this process.

2. Cost of rephasing

2.1. Penalties are typically built into all contracts, including construction contracts, delivery contracts, loan agreements, lease agreements, advance payment and trustee borrowing agreements. For every project such penalties and any additional costs which would be incurred in case of rephasing by the state entities should be assessed.

2.2. The legal implications of such a rephasing should also be analysed.

Since 1983, White and Case has incorporated in every contract signed by the Republic termination clauses which outline the conditions for early termination. White and Case should be able to compile a status report for the major projects negotiated since 1983, setting out the impact of terminating each project. 
Offshore Loans 173

\section{Document 5}

5th July, 1991

\section{Memorandum}

To: $\quad$ H.E. Coordinating Minister Radius Prawiro

H.E. Governor Adrianus Mooy

From: The Advisory Group

The intent of the attached note is to suggest the positive tone which we believe should be adopted in connection with any announcements relating either to the Bank Indonesia queue for banks or a possible announcement by the Coordinating Minister concerning state-related projects. 


\section{Document 6}

5th July, 1991

\section{Memorandum}

To: H.E. Coordinating Minister Radius Prawiro

H.E. Minister J. B. Sumarlin

H.E. Governor Adrianus Mooy

H.E. Minister Saleh Afiff

Professor Widjojo Nitisastro

Prof. Dr. Ali Wardhana

cc: Dr. Irzan Tandjung

Mrs. Buly O. Surjaatmadja

Mr. Jusuf Anwar

Dr. Syahril Sabirin

From: The Advisory Group

Re: Ordering of State Project Financing

1. The overriding objective in establishing control over commercial borrowing for state and state-related projects is that the Republic must be assured of its ability to refinance its existing borrowings and thereby maintain its credit standing internationally by:

- not overcrowding the market;

- decreasing its debt service ratio to $20-25 \%$ as soon as possible (from a current $33 \%$, including private debt, as estimated by the World Bank); and

- avoiding all unnecessary shocks to the international financial community, i.e., presenting current measures in a positive way.

2. The number and magnitude of recent Indonesian borrowings is such that a queueing procedure is required for state and state-related projects which are to be commercially financed in foreign currency.

3. The projects subject to the queue should include all state and state-related projects (in excess of a size to be agreed upon) relying upon commercial financing in foreign currency. Also included should be private so-called "non-recourse" projects which involve some state participation; for example, through minority equity participation, and guarantees of any kind, including off-take and throughput agreements.

So called "Blue Book" projects, which are financed from bilateral and multilateral sources need not be included in the queue, as adequate monitoring currently exists.

4. We suggest that the queue be established immediately for projects for which no commercial contracts and/or financing arrangements have yet been finalised. At the same time, work should begin on an analysis of the benefits and costs resulting from the eventual postponement of projects in various categories of more advanced development, e.g. those which may be signed but not yet effective, and those which are effective but on which no funds have been disbursed. ${ }^{1}$ We are reluctant at this stage to review those projects already under construction because of the negative connotations in such an action, as was realized in 1983.

5. Very soon, guidelines should be issued to state companies to suspend current negotiations and the signing of new contracts that may prove costly to suspend at a later date.

\footnotetext{
${ }^{1}$ The legal consequences of delaying or terminating projects may be significant. White \& Case should be
} consulted on any such actions. 
6. The criteria by which projects should be advanced in the queue were discussed in our earlier memorandum of June 6, and are summarized in Annex I.

7. Having established the queue and the means of evaluating the projects within it, the amount of commercial financing which will be permitted must be set annually.

\begin{tabular}{|c|c|c|c|}
\hline \multicolumn{4}{|c|}{$\begin{array}{l}\text { Borrowing capacity for Indonesia } \\
\text { from commercial markets in } 1991^{\text {a }}\end{array}$} \\
\hline & \multirow{2}{*}{$\begin{array}{c}1990 \\
\text { US\$ bn } \\
\text { Realised }\end{array}$} & \multicolumn{2}{|c|}{$\begin{array}{c}1991 \\
\text { US\$ bn }\end{array}$} \\
\hline & & $\begin{array}{l}\text { Realised } \\
\text { Jan-May }\end{array}$ & $\begin{array}{r}\text { Projected } \\
\text { Jan-Dec }\end{array}$ \\
\hline $\begin{array}{l}\text { Total } \\
\text { of which: }\end{array}$ & 7.25 & 3.44 & 5.7 \\
\hline Bank Indonesia & 0.4 & - & 0.4 \\
\hline State enterprises & 1.75 & $1.1^{\mathrm{b}}$ & 1.1 \\
\hline Banks & 2.4 & 0.9 & $1.5^{\mathrm{c}}$ \\
\hline State banks & 1.4 & 0.55 & \\
\hline Private banks & 1.0 & 0.35 & \\
\hline Private corporates & 2.7 & 1.44 & $2.7^{c}$ \\
\hline
\end{tabular}

a Committed amounts.

b US $\$ 330$ million for Musi refinery; US $\$ 750$ million for Train F currently in syndication.

${ }^{C}$ It is assumed based on the realised figures in 1990 and January-May 1991 that banks will borrow $\$ 0.5$ million in the remainder of 1991 and that private sector corporate borrowings will equal 1990 totals.

In 1990, the Republic of Indonesia on an aggregate basis raised approximately US\$ 7.25 billion in commercial markets which was generally felt by foreign lenders to be excessive and to have strained market capacity. For 1991 we believe that an amount of $\$ 5-6$ billion is the maximum permissible borrowing level.

On this basis we believe that there should be no additional project borrowings in commercial markets for the remainder of $1991 .^{2}$

8. Future annual borrowing limits in the commercial markets for projects should consider the needs of:

- the Republic;

- the banking sector (state and private); and

- the purely private sector.

Government policy deems that the private sector should not be subject to control, and accordingly the public project sector must settle for the funds remaining when the above sectors have satisfied their financing requirements.

The yearly borrowing limits will additionally take into account:

- the current account deficit;

- the absolute level of external indebtedness, which is extremely high;

- the goal of reducing the debt service ratio; and

- the capacity of commercial markets.

2 In terms of the current account deficit, the benefits of delaying or eliminating 1991 project financings will only be realized in 1992 and subsequently. 


\section{The Editors}

Based on the above considerations, we believe the amount available for the Republic from commercial sources will continue to be limited. In addition, the Republic should try to reduce its debt service ratio. This implies the amount available for the state enterprises for the next few years will remain modest.

9. The measures should be presented as a response to the rapid growth of the Indonesian economy, necessitating new procedures to deal with the expansion resulting from the success of the policies of deregulation.

ANNEX I

\section{Criteria to set priorities for projects in the queue}

In establishing this queue and deciding which projects should receive priority, the following major criteria should be taken into account:

- Foreign exchange implications

The foreign exchange generating capacity of the project should be considered and projects which will generate positive foreign exchange flows in the shortest period of time should be emphasized; the foreign,exchange debt coverage ratio could provide a useful guide in this evaluation;

- Balance of payment implications

Export-oriented projects should be emphasized and projects with a high import content should be given a lower priority, particularly given the current balance of payments constraints of the Republic;

- Magnitude

Large scale projects should be particularly carefully scrutinised. It may well be that certain such projects are felt to be of priority, but a single substantial project, of say, US\$1 billion, may consume a significant amount, if not all, of the total commercial resources available for project financing in a single year;

- Financing structure

The financing structure of each project should be evaluated:

(i) the higher the equity component and the lower the percentage of debt financing the better;

(ii) the higher the debt component from official rather than commercial sources the better; and

(iii) the extent to which the project is genuinely non-recourse should also be considered; for example, a trustee borrowing structure is preferable to an advance payments structure.

\section{- Policy implications}

The impact of specific projects on the overall development policies of the Republic also needs to be considered e.g. certain projects, typically infrastructure projects and labor intensive projects may be given priority because of their social or technological implications. We understand that some priority sectors have already been identified viz. electricity and telecommunications. 
Offshore Loans

\section{Document 7}

8th July, 1991

Memorandum

For: Dr. Irzan Tandjung

Assistant to the Minister for Monetary Affairs,

Balance of Payments and Public Finance, EKUIN

cc: $\quad$ Mr. Jusuf Anwar-Director of External Funds Department of Finance

Dra. Ny. Buly O. Surjaatmadja-Vice Chairman, Bappenas

Mr. Djamalius Luddin-Director International, Bank Indonesia

From: The Advisory Group

Re: Background to Project Review

We refer to our memorandum dated 8th July "Project Review" with the attached table, submitted jointly with White \& Case, and summarising the potential legal and financial implications of a postponement/termination of certain Pertamina projects.

The Advisory Group's evaluation of the potential impact on international financial markets has been made on the basis of the current status of these projects and on the assumption that any public announcements relating to these projects is made in a timely and positive manner. If, however, an announcement of the new "guidelines" is not made shortly, it is possible that a number of these projects may proceed further into negotiation, which would potentially increase the impact of any postponement/termination beyond that currently suggested in the attached table.

The projects you have asked us to review fall broadly into two categories: (i) projects whose postponement/termination would have a significant impact on the international financial markets and (ii) projects where the impact on the financial markets would be limited. Projects in category (i) include EXOR I for which financing was signed last year and Musi which was signed recently. In addition, a postponement of the Train $\mathrm{F}$ financing could also have an adverse impact on the Republic's image in the international financial community since the financing is currently in an advanced stage of syndication and given the original difficulties surrounding this financing and the fact that the syndication is now proceeding very successfully.

We have confined our analysis in the table attached to our memorandum "Project Review" to those Pertamina projects which we were specifically requested to review. However, as outlined in our other memoranda on the subject of project coordination, we believe that all projects which are seeking financing from external commercial markets and in which the state has any involvement should be reviewed. These would include:

(1) Pertamina-related projects (i.e., where Pertamina is involved through minority equity participations, off-take or throughput agreements, etc.) in the oil and gas and petrochemical sectors;

(2) Projects in the strategic industries;

(3) Garuda projects; and

(4) BOT and BOO projects.

Encl. 
178 The Editors

\section{Document 8}

\section{Memorandum}

To: H.E. Coordinating Minister Radius Prawiro

H.E. Governor Adrianus Mooy

From: The Advisory Group

Date: July 8th, 1991

Re: Possible Draft Framework for a Press Release

In view of the success of the Government's deregulation policies and the growth of Indonesia's economy, many state and state-related projects are being developed which will need foreign exchange financing.

Since so many projects seeking external financing simultaneously might create a sense of unease among foreign commercial lenders, it has been decided to establish a queueing system for projects under study, which will be monitored by the MOF, BI and Bappenas.

All state and state-related projects above US\$ .... million which are to be financed by foreign commercial banks or in foreign currencies will be included in this queue.

So-called "private non-recourse" projects for which state assistance is required, in the form of equity participations, or guarantees of any kind including offtake, purchase or throughput contracts will also be subject to the queueing procedure.

State banks' offshore borrowings and guarantees in foreign currency will also be monitored and be included in a queueing procedure established by Bank Indonesia. 


\section{Document 9}

17th July, 1991

Memorandum

To: $\quad$ Ministry of Finance, Jakarta, Indonesia

Attn: H.E. Prof. Radius Prawiro, Co-ordinating Minister for the Economy, Finance and Industry H.E. Prof. Dr. J.B. Sumarlin, Minister of Finance

To: $\quad$ Bank Indonesia, Jakarta, Indonesia

H.E. Prof. Dr. Adrianus Mooy, Governor

From: The Advisory Group

Re: Project Co-ordination/Arun Aromatics Project

We would like to draw to your attention the reaction of the international commercial markets in response to recent developments on the US\$ 1.4 billion financing of the Arun Aromatics project.

We understand that the arranger of the project, Mitsui \& Co., has recently circulated an information memorandum and a term sheet on the project to approximately 25 Japanese banks, requesting their participation in the project. We have been told that the banks have been asked to indicate their interest during July so this transaction is effectively in pre-syndication. For your information, the proposed terms we have heard mentioned for this project are very expensive.

This approach to the markets for financing for the Arun project clearly conflicts with the Train $F$ project, which as you may be aware, is in the final stages of syndication. There is concern that the success to date of the Train F syndication may be jeopardized. There is also criticism in the markets of Pertamina, and implicitly of the Indonesian authorities, for having violated 'clear market practice' by giving Mitsui the green light to proceed with the financing of the Arun project while the Train F syndication was still underway.

This incident reinforces the market's impression of the lack of co-ordination of borrowings in the commercial markets by Indonesian entities and lends support to the Indonesian authorities' intention to implement measures to co-ordinate commercial market financings for projects. The implications of Pertamina's utilising an additional US $\$ 1.4$ billion of commercial market funds are potentially damaging to the Republic and would almost certainly adversely affect Bank Indonesia's 1991 borrowing programme.

Further to our various meetings about project co-ordination and debt monitoring in Jakarta recently, we remain at your disposal to provide any assistance that may be required to follow up on these matters. 


\section{Document 10}

\section{Memorandum}

To: Ministry of Finance, Jakarta, Indonesia

Attn: H.E. Prof. Radius Prawiro, Co-ordinating Minister for the Economy, Finance and Industry H.E. Prof. Dr. J. B. Sumarlin, Minister of Finance

To: Bank Indonesia, Jakarta, Indonesia

H.E. Prof. Dr. Adrianus Mooy, Governor

From: The Advisory Group

Re: Project Co-ordination/Java Pipeline Project

Further to our memorandum of 18th July, 1991, about the US\$1.4 billion financing for the Arun Aromatics project currently in pre-syndication, we now understand that a mandate has just been awarded to Mitsubishi to arrange a US\$ 470 million financing for the North Bali/Java pipeline project. This financing is expected to include a US $\$ 300$ million loan to be syndicated with international banks and a US $\$ 100$ million loan to be provided by domestic institutions. If, however, past precedent is followed, the US $\$ 100$ million facility, albeit provided by domestic institutions, will almost certainly be financed offshore.

The announcement of another financing by Pertamina, following, as it does, immediately on the approach to the market for a US\$1.4 billion financing for the Arun Aromatics project, which itself clashed with the US $\$ 750$ million Train F syndication, highlights the need for stronger official guidance on project financings in external markets.

As we have stated previously, there is a clear perception in the international financial market that no priorities and guidelines exist for an orderly approach to external commercial markets by Indonesian projects; we continue to be concerned that steps should be taken as soon as possible to reassure the international financial community that "clear market practice" will be respected and that the finite commercial resources available will be properly allocated.

We are planning another visit to Jakarta shortly and look forward to the opportunity of discussing these matters further with you. 


\section{Document 11}

30th August, 1991

\section{Memorandum}

To: $\quad$ H.E. Coordinating Minister Radius Prawiro

H.E. Minister J. B. Sumarlin

H.E. Governor Adrianus Mooy

H.E. Minister Saleh Afiff

Professor Widjojo Nitisastro

Prof. Dr. Ali Wardhana

Copies to: Dr. Irzan Tandjung

Mrs. Buly O. Surjaatmadja

Mr. Jusuf Anwar

Dr. Syahril Sabirin

Dr. Boediono

From: The Advisory Group

Re: $\quad$ Establishment of a maximum borrowing ceiling from the commercial markets for Indonesian borrowers for FY 1991/92

\section{Introduction}

We understand that the Indonesian authorities are about to establish a team of senior officials to co-ordinate all medium and long term external borrowings deriving from non-IGGI and other nonofficial sources, including borrowings for export credits and the related down payment financings.

One of the first tasks of the debt management team will be to identify the maximum amount which the Republic as a whole can borrow from commercial markets in FY 1991/92, taking into account the impact of such borrowing on (a) the balance of payments; (b) the debt service ratio; and (c) the continuing availability of funds in the commercial markets on suitable terms which do not jeopardise the creditworthiness of the Republic.

As requested, we have outlined below our recommendations on the establishment of a borrowing ceiling for FY 1991/92. The proposed ceiling would be the maximum amount which could be borrowed by all categories of Indonesian borrowers in FY 1991/92. If a particular category of borrower does not borrow the total anticipated amount, the shortfall should not automatically be allocated to another category of borrower. The Republic should aim to minimise its external commercial borrowing, since its external indebtedness is already excessive.

It is our view that such a borrowing limit should not be publicly announced but should essentially be used for internal purposes by the debt committee as one tool for managing the external debt. Some flexibility will also be required in the administration of this ceiling to reflect changes in the economic and financial situation both in Indonesia and the commercial markets.

II. Borrowing from external commercial markets in FY 1991/92

The following table sets out the anticipated commercial borrowing by Indonesian borrowers in FY 1991/92. Attached in Annex I is some background information on the assumptions used in compiling the following table:- 


\begin{tabular}{|c|c|c|c|c|}
\hline & \multirow[b]{2}{*}{$\begin{array}{c}1990 \\
\text { US\$ bn } \\
\text { Realised }\end{array}$} & \multicolumn{3}{|c|}{ FY 1991/92 } \\
\hline & & $\begin{array}{l}\text { Realised } \\
\text { Apr-Aug }\end{array}$ & $\begin{array}{c}\text { US\$ bn } \\
\text { Projected } \\
\text { Sept-Mar }\end{array}$ & $\begin{array}{c}\text { Total } \\
\text { Anticipated } \\
\text { FY 1991/92 }\end{array}$ \\
\hline $\begin{array}{l}\text { Total }{ }^{\mathrm{b}} \\
\text { of which: }\end{array}$ & 7.3 & 2.5 & 3.4 & 5.9 \\
\hline Bank Indonesia & 0.4 & - & 0.4 & 0.4 \\
\hline State enterprises & 1.8 & $1.1^{\mathrm{c}}$ & $0.4^{\mathrm{d}}$ & 1.5 \\
\hline Banks & 2.4 & 1.0 & 0.5 & 1.5 \\
\hline State Banks & (1.4) & $(0.6)$ & & \\
\hline Private Banks & (1.0) & $(0.4)$ & & \\
\hline Private corporates & 2.7 & 0.4 & 2.1 & 2.5 \\
\hline \multicolumn{5}{|l|}{ Calendar year } \\
\hline \multicolumn{5}{|c|}{${ }^{b}$ Committed amounts; medium and long term debt (i.e., 12 months and longer) } \\
\hline \multicolumn{5}{|c|}{${ }^{c}$ Includes Musi refinery (US\$330 million) and Train F (US\$750 million) } \\
\hline d Bali North pipeline (US & 0 million) & & & \\
\hline
\end{tabular}

A total volume of US $\$ 5.9$ billion $^{3}$ is anticipated for the present fiscal year, based on the amount already realised in the first five months of the year and the borrowing projected for the remaining seven months. This table does not attempt to quantify the maximum amount that would be available from the market for the Republic, nor does it show a level of borrowing which should be regarded as prudent. It is rather a pragmatic estimate based on expected market availability and projected financing requirements.

In 1990 a total of US $\$ 7.3$ billion was raised, a significant increase on the total US $\$ 2.7$ billion borrowed in 1989. The level of commercial borrowing in 1990 created widespread concern among both official and commercial lenders and was generally felt to be excessive. A reduction from last year's level of US\$7.3 billion is essential as part of a programme to maintain accessibility of Indonesian entities to the commercial markets on favourable terms and conditions.

The total of US $\$ 5.9$ billion does not include the Arun Aromatics financing of US\$1.4 billion. Even though the commercial market may be able to absorb this transaction, a borrowing of this magnitude in present market conditions would not be prudent. It should be noted that approximately 50 per cent. of this financing would be supported by a guarantee from the Japanese project sponsor. The recent US $\$ 750$ million financing for Train F also included a 40 per cent. tranche guaranteed by the Japanese project sponsor. The need for substantial Japanese support for these large scale Pertamina projects demonstrates the commercial market's hesitation to accept such large amounts of Indonesian project risk.

We recognise that agreements have recently been signed which create certain financial obligations for Pertamina in the event of a postponement of this project and furthermore that a delay will inevitably cause some resentment from the bankers and sponsors involved. This notwithstanding, we believe that it would be inadvisable to proceed with the financing in present economic circumstances.

Attention should be paid to the warning signals given by the lending banks. Once banks feel that a country has exceeded its borrowing limits, they will suddenly stop lending, short term lines will not be refinanced and the country will face a severe shortage of funds.

${ }^{3}$ This figure compares with a total volume of US\$5.7 billion projected for calendar year 1991 in our memorandum of 5th July, 1991. This net increase of US $\$ 200$ million is accounted for by a US $\$ 400$ million increase in the state enterprises category reflecting the Bali North pipeline financing and a decrease of US\$200 million in the level of private sector borrowing to take into account the recent postponement of certain financings. 


\section{Debt and Debt Service Ratio}

The absolute level of outstanding medium and long term debt, estimated at around US $\$ 60$ billion (including short term external debt is estimated at US $\$ 70$ billion) as of December 1990, is already high and makes Indonesia the fifth most indebted developing country in the world. Annex II compares Indonesia's debt characteristics with those of four heavily indebted nations, namely Brazil, Mexico, Argentina and India. Of these, Brazil, Mexico and Argentina have arranged numerous reschedulings/restructurings of their bilateral and bank debt over the last decade and only Mexico has been able recently to return to the capital markets. Although India has not rescheduled yet, it is faced with a shortage of liquidity and an acute difficulty in meeting its external payment obligations, largely due to its creditors' unwillingness to renew their commercial credit lines. India is currently endeavouring to reach agreement with the INF on establishing an economic programme.

As shown in Annex III, "Debt Service Ratio projections: FY 1991/92 to FY 1995/96," the debt service ratio of the Republic (taking into account the total medium and long term debt of the Republic) is estimated at 33 per cent in FY 1990 and is at a level which is already too high. Both the amount of debt and the debt service ratio should be reduced over the next few years in order to decrease the vulnerability of the Republic to adverse changes in the international environment. The anticipated level of borrowings over the next few years does not, however, allow for a reduction in this debt stock nor for any improvement in the debt service ratio. Two alternatives are proposed: the first based on a well co-ordinated debt management programme, illustrated in Annex III (a), and the second presenting a 'no debt co-ordination' scenario, set out in Annex III (b).

Even with a well co-ordinated debt management scenario which would include a very restricted level of borrowing by state enterprises-assumed by us to be at a level of $\$ 0.8$ billion per annumand an assumption of high export growth, the debt service ratio reaches 40 per cent. and remains above its present level for the next five years. In addition, total debt outstanding continues to rise, the debt structure of the Republic continues to deteriorate, and the financing requirement from the commercial market consistently approaches US $\$ 6.0$ billion on an annual basis.

Under the 'no debt co-ordination' case with the high export growth assumption, the debt service ratio deteriorates more severely in 1991 and 1992 and then remains at around the 40 per cent. level during the projection period. With the low export growth assumption, the debt service ratio would continuously deteriorate and reach 44 per cent. in FY 1995.

The projections indicate that little borrowing room is available for the Republic and the state enterprises, once the private sector and the banking sector have satisfied their requirements.

\section{Balance of Payments}

An increase in external borrowings by the public and private sectors would inevitably lead to an increase in Indonesia's imports and result in greater pressures on the current account deficit. It should be noted that the scenarios outlined below are based only on rough estimations and indicate an order of magnitude of the pressures on the current account deficit.

Based on the assumptions and projections outlined in Annex III (a) and (b) the estimates indicate a significant deterioration in the current account deficit in FY 1991. In Annex III (a) under a co-ordinated debt management programme (i.e., the Arun Aromatics project is assumed not to be committed in FY 1991 and state enterprises including Pertamina are assumed to borrow US $\$ 0.8$ billion each year in FY 1992 to FY 1995) the current account deficit in FY 1991 increases to around US\$6 billion and remains at this level during the projection period. In the 'no debt co-ordination' scenario, (i.e., Arun Aromatics project is assumed to be committed in FY 1991 and state enterprises including Pertamina borrow US\$4 billion each year during FY 1992 to FY 1995) the current account deficit is estimated to increase to well above US\$6 billion in FY 1991 and to continue deteriorating to a level above US\$7 billion in FY 1992 and increase dramatically to US\$10 billion in FY 1995.

These projections demonstrate that continued borrowings by state enterprises, particularly large and capital intensive Pertamina projects would lead to unsustainable current account deficits. Even co-ordinated borrowing by state enterprises (annual commitment of US0.8 billion in FY 1992 to FY 1995) may lead to a deterioration in the current account deficit over the course of the next few years. 


\section{The Editors}

Therefore, it is particularly important to aim to reduce imports which will lead to a reduction in borrowings. Furthermore, selectivity of investment projects is fundamental and priority should be given to projects which in terms of foreign exchange have a quick net positive cash flow. In addition, selectivity in terms of financing sources is important, and priority for long term financings with substantial grace period should be given.

\section{Conclusion}

Giving due consideration to the consequences of additional Indonesian commercial borrowings on the Republic's debt servicing capacity, the balance of payments deficit, and its acceptability as a long term borrower, we believe that such borrowings by all Indonesian entities from the commercial markets should be limited as far as possible, and in any event, to not more than US\$6 billion per annum in FY 1991/92. For following years, a very careful investment and financing strategy should be designed to reduce the current account deficit and improve the debt service ratio to reach a level of below 30 per cent. as soon as practicable.

\section{Assumptions used in compiling commercial borrowing table for FY 1991/92}

ANNEX I

The figures included in the table on page two, setting out "the anticipated commercial borrowing by Indonesian borrowers in FY 1991/92" are based on the following assumptions:

(i) As specified in note (2) to the table, the borrowings are shown on a commitment basis. Once the lenders have committed to provide the financing, it is the committed amount which will be counted against the overall Indonesia country limit, regardless of when the funds are actually drawn down.

(ii) Private corporate borrowings would not be restricted by the Indonesian authorities in order to maintain the development of the private sector.

With reference to the realised borrowing figures for 1990 and the first five months of FY 1991/92, and taking into account the slow-down of the domestic economy and in particular, the real estate sector, borrowing of approximately $\$ 2.5$ billion for the pure private corporate sector would be realistic in FY 1991/92.

(iii) Banks (state and private) borrowed $\$ 2.4$ billion in 1990 and US $\$ 0.6$ billion in the first five months of FY 1991/92. Based on more accurate information available to Bank Indonesia, bank borrowing in FY 1991/92 may be significantly in excess of the sum indicated in the table. Following Minister Sumarlin's guidelines to state banks they have refrained from any significant market activity. We have assumed, however, that some refinancing of short-term facilities (i.e., those with one year maturities contracted in FY 1990/91) may be necessary during the second part of the current fiscal year.

(iv) For State enterprise borrowings, we have assumed that only three Pertamina projects should be financed in FY 1991/92. Musi refinery (US\$330 million), Train F (US\$750 million) and Bali North pipeline (US $\$ 400$ million). Financing for the first two has already been signed and we understand that the Bali North pipeline project is essential as part of the overall development of the Kangean gas field and the PLN Gresik power plant.

(v) Bank Indonesia borrowed US $\$ 400$ million in 1990 . We have assumed that Bank Indonesia would borrow a comparable amount during FY 1991/92. Approximately US\$ million of the standby lines will be maturing in FY $1991 / 92$ and at least US $\$ 400$ million will be required to replenish the standby lines. 
Annex II. Comparative Debt Figures of Most Heavily Indebted LDCs, 1989 (billion US\$. \%)

\begin{tabular}{lrrrrr}
\hline \hline & 1. Brazil & 2. Mexico & 3. Argentina & 4. India & 5. Indonesia \\
\hline Total debt stock (EDT) & 111.290 & 95.641 & 64.745 & 62.509 & 53.111 \\
Long-term debt outstanding (LDOD) & 90.292 & 80.256 & 53.229 & 56.253 & 45.477 \\
EDT plus undisbursed debt & 124.325 & 101.649 & 66.976 & 83.414 & 72.083 \\
Debt export ratio (EDT/XGS) & $301.6 \%$ & $262.9 \%$ & $537.0 \%$ & $258.4 \%$ & $210.6 \%$ \\
Debt GNP ratio (EDT/GNP) & $24.1 \%$ & $51.2 \%$ & $119.7 \%$ & $23.9 \%$ & $59.8 \%$ \\
Debt Service ratio (total DS/XGS) & $31.3 \%$ & $39.5 \%$ & $36.1 \%$ & $26.3 \%$ & $35.2 \%$ \\
Share of short-term debt to EDT & $16.7 \%$ & $10.8 \%$ & $13.0 \%$ & $7.5 \%$ & $13.2 \%$ \\
Share of concessional debt to EDT & $2.6 \%$ & $0.4 \%$ & $0.3 \%$ & $41.2 \%$ & $28.6 \%$ \\
Share of private debt to EDT & $5.4 \%$ & $4.2 \%$ & $2.8 \%$ & $2.4 \%$ & $8.7 \%$ \\
\hline
\end{tabular}

Source: World Bank, "World Debt Tables, 1990/91 Edition," terms as defined therein.

Note: 1)Total debt stock includes short-term debt. 2) Concessional debt means loans with a grant element of $25 \%$ or more. 3) XGS means export of goods and services. 
Annex III a. Debt Service Ratio Projection

-Debt Coordination Case-

\begin{tabular}{|c|c|c|c|c|c|c|}
\hline & FY90 & FY91 & FY92 & FY93 & FY94 & FY95 \\
\hline \multicolumn{7}{|l|}{ DSR, debt service/export goods } \\
\hline -High export growth & $33.1 \%$ & $38.8 \%$ & $40.6 \%$ & $39.1 \%$ & $37.5 \%$ & $35.8 \%$ \\
\hline - Low export growth & $33.1 \%$ & $38.8 \%$ & $41.9 \%$ & $41.8 \%$ & $41.4 \%$ & $40.9 \%$ \\
\hline \multicolumn{7}{|l|}{ DSR Public sector } \\
\hline -High export growth & $26.7 \%$ & $28.3 \%$ & $26.6 \%$ & $25.2 \%$ & $23.7 \%$ & $22.3 \%$ \\
\hline - Low export growth & $26.7 \%$ & $28.3 \%$ & $27.5 \%$ & $26.9 \%$ & $26.2 \%$ & $25.5 \%$ \\
\hline \multicolumn{7}{|l|}{ Export of goods } \\
\hline -High growth & 28.1 & 28.8 & 31.7 & 35.0 & 38.5 & 42.5 \\
\hline -Low growth & 28.1 & 28.8 & 30.7 & 32.7 & 34.9 & 37.2 \\
\hline Debt service total & 9.3 & 11.2 & 12.9 & 13.7 & 14.4 & 15.2 \\
\hline _Public sector debt service & 7.5 & 8.2 & 8.4 & 8.8 & 9.1 & 9.5 \\
\hline Amortization & 4.7 & 5.1 & 5.3 & 5.5 & 5.7 & 5.9 \\
\hline Interest payments & 2.8 & 3.0 & 3.1 & 3.3 & 3.4 & 3.5 \\
\hline -Private sector debt service & 1.8 & 3.0 & 4.4 & 4.9 & 5.3 & 5.7 \\
\hline Amortization & 1.0 & 2.1 & 3.1 & 3.4 & 3.7 & 4.0 \\
\hline Interest payments & 0.8 & 0.9 & 1.4 & 1.5 & 1.6 & 1.8 \\
\hline Debt outstanding total & 58.0 & 61.5 & 64.8 & 68.0 & 71.2 & 74.6 \\
\hline -Public sector & 47.6 & 49.2 & 51.3 & 53.3 & 55.2 & 57.4 \\
\hline -Private sector & 10.4 & 12.3 & 13.5 & 14.7 & 15.9 & 17.2 \\
\hline Gross borrowing disbursement & 10.7 & 10.7 & 11.7 & 12.1 & 12.6 & 13.4 \\
\hline -Public sector & 5.6 & 6.7 & 7.4 & 7.5 & 7.7 & 8.1 \\
\hline IGGI \& export credits & 5.0 & 5.2 & 5.6 & 6.0 & 6.4 & 6.8 \\
\hline Bank Indonesia & 0.0 & 0.4 & 0.5 & 0.5 & 0.5 & 0.5 \\
\hline State enterprises & 0.6 & 1.1 & 1.4 & 1.0 & 0.8 & 0.8 \\
\hline -Private sector & 5.1 & 4.0 & 4.3 & 4.6 & 4.9 & 5.2 \\
\hline State \& private banks & 2.4 & 1.5 & 1.6 & 1.7 & 1.8 & 2.0 \\
\hline Private corporates & 2.7 & 2.5 & 2.7 & 2.9 & 3.1 & 3.3 \\
\hline Gross borrowing commitments & 12.3 & 11.4 & 11.5 & 12.2 & 12.9 & 13.8 \\
\hline -Public sector & 7.2 & 7.4 & 7.2 & 7.6 & 8.0 & 8.5 \\
\hline IGGI \& export credits & 5.0 & 5.5 & 5.9 & 6.3 & 6.7 & 7.2 \\
\hline Bank Indonesia & 0.4 & 0.4 & 0.5 & 0.5 & 0.5 & 0.5 \\
\hline State enterprises & 1.8 & 1.5 & 1.6 & 1.7 & 1.8 & 2.0 \\
\hline -Private sector & 5.1 & 4.0 & 4.3 & 4.6 & 4.9 & 5.2 \\
\hline State \& private banks & 2.4 & 1.5 & 1.6 & 1.7 & 1.8 & 2.0 \\
\hline Private corporates & 2.7 & 2.5 & 2.7 & 2.9 & 3.1 & 3.3 \\
\hline Commercial market commitment & 7.3 & 5.9 & 5.6 & 5.9 & 6.2 & 6.5 \\
\hline
\end{tabular}


Annex III b. Debt Service Ratio Projection

-No Debt Coordination Case-

\begin{tabular}{|c|c|c|c|c|c|c|}
\hline & FY90 & FY91 & FY92 & FY93 & FY94 & FY95 \\
\hline \multicolumn{7}{|l|}{ DSR, debt service/export goods } \\
\hline - High export growth & $33.1 \%$ & $38.8 \%$ & $40.8 \%$ & $40.0 \%$ & $39.4 \%$ & $38.7 \%$ \\
\hline - Low export growth & $33.1 \%$ & $38.8 \%$ & $42.2 \%$ & $42.8 \%$ & $43.5 \%$ & $44.2 \%$ \\
\hline \multicolumn{7}{|l|}{ DSR Public sector } \\
\hline -High export growth & $26.7 \%$ & $28.3 \%$ & $26.8 \%$ & $26.1 \%$ & $25.6 \%$ & $25.2 \%$ \\
\hline - Low export growth & $26.7 \%$ & $28.3 \%$ & $27.7 \%$ & $27.9 \%$ & $28.3 \%$ & $28.7 \%$ \\
\hline \multicolumn{7}{|l|}{ Export of goods } \\
\hline -High growth & 28.1 & 28.8 & 31.7 & 35.0 & 38.5 & 42.5 \\
\hline -Low growth & 28.1 & 28.8 & 30.7 & 32.7 & 34.9 & 37.2 \\
\hline Debt service total & 9.3 & 11.2 & 13.0 & 14.0 & 15.2 & 16.4 \\
\hline -Public sector debt service & 7.5 & 8.2 & 8.5 & 9.1 & 9.9 & 10.7 \\
\hline Amortization & 4.7 & 5.1 & 5.3 & 5.7 & 6.2 & 6.7 \\
\hline Interest payments & 2.8 & 3.0 & 3.2 & 3.4 & 3.7 & 4.0 \\
\hline - Private sector debt service & 1.8 & 3.0 & 4.4 & 4.9 & 5.3 & 5.7 \\
\hline Amortization & 1.0 & 2.1 & 3.1 & 3.4 & 3.7 & 4.0 \\
\hline Interest payments & 0.8 & 0.9 & 1.4 & 1.5 & 1.6 & 1.8 \\
\hline Debt outstanding total & 58.0 & 62.0 & 66.8 & 72.4 & 78.2 & 84.1 \\
\hline -Public sector & 47.6 & 49.6 & 53.3 & 57.6 & 62.3 & 66.9 \\
\hline -Private sector & 10.4 & 12.3 & 13.5 & 14.7 & 15.9 & 17.2 \\
\hline Gross borrowing disbursement & 10.7 & 11.2 & 13.2 & 14.7 & 15.8 & 16.6 \\
\hline -Public sector & 5.6 & 7.2 & 9.0 & 10.1 & 10.9 & 11.3 \\
\hline IGGI \& export credits & 5.0 & 5.2 & 5.6 & 6.0 & 6.4 & 6.8 \\
\hline Bank Indonesia & 0.0 & 0.4 & 0.5 & 0.5 & 0.5 & 0.5 \\
\hline State enterprises & 0.6 & 1.6 & 2.9 & 3.6 & 4.0 & 4.0 \\
\hline -Private sector & 5.1 & 4.0 & 4.3 & 4.6 & 4.9 & 5.2 \\
\hline State \& private banks & 2.4 & 1.5 & 1.6 & 1.7 & 1.8 & 2.0 \\
\hline Private corporates & 2.7 & 2.5 & 2.7 & 2.9 & 3.1 & 3.3 \\
\hline Gross borrowing commitments & 12.3 & 12.8 & 14.7 & 15.4 & 16.1 & 17.0 \\
\hline -Public sector & 7.2 & 8.8 & 10.4 & 10.8 & 11.2 & 11.7 \\
\hline IGGI \& export credits & 5.0 & 5.5 & 5.9 & 6.3 & 6.7 & 7.2 \\
\hline Bank Indonesia & 0.4 & 0.4 & 0.5 & 0.5 & 0.5 & 0.5 \\
\hline State enterprises & 1.8 & 2.9 & 4.0 & 4.0 & 4.0 & 4.0 \\
\hline -Private sector & 5.1 & 4.0 & 4.3 & 4.6 & 4.9 & 5.2 \\
\hline State \& private banks & 2.4 & 1.5 & 1.6 & 1.7 & 1.8 & 2.0 \\
\hline Private corporates & 2.7 & 2.5 & 2.7 & 2.9 & 3.1 & 3.3 \\
\hline Commercial market commitment & 7.3 & 7.3 & 8.8 & 9.1 & 9.4 & 9.7 \\
\hline
\end{tabular}




\section{The Editors}

\section{Note to Annex III $a \mathcal{E} b$}

1. Figures for FY 1990 are based on both estimated and realized data. Figures for FY 1991 onwards are projections. Sources for the data include Bank Indonesia, the World Bank and IMF.

2. The high export growth case assumes a $10.2 \%$ p.a. average export growth rate (oil and gas exports, $3.0 \%$ p.a. and non-oil exports $15.0 \%$ p.a.) throughout projection period. The low export growth case assumes a $6.6 \%$ p.a. average export growth rate (oil and gas exports $1.5 \%$ p.a. and non-oil exports $10.0 \%$ p.a.).

3. Debt includes all external debt of Indonesia but excludes short-term debt and borrowing from IMF. 4. Public sector debt includes government debt (ie. IGGI and other ODA, export credits. BI general purpose borrowings) and state enterprise borrowings (includes Pertamina non recourse projects). Private sector debt includes state and private banks and private corporate borrowings.

5. As of December 1990, public sector debt consists of government debt $\$ 44.5$ billion, state enterprise debt $\$ 0.6$ billion and Pertamina LNG expansion $\$ 2.5$ billion.

6. Public debt is assumed to carry an average interest rate of $6.4 \%$ p.a. and an average maturity of 9.3 years throughout projection period. Private sector debt is assumed to carry an average interest rate of $9.0 \%$ p.a. and an average maturity of 5 years in FY 1991 and $11.0 \%$ p.a. and an average maturity of 4 years in FY 1992 to FY 1995.

7. Both disbursement and commitment of IGGI ODA and export credits are assumed to increase at a GDP growth rate of $7.0 \%$ p.a.

8. Bank Indonesia is assumed to borrow $\$ 0.4$ billion in FY 1991 and $\$ 0.5$ billion each year in FY 1992 to FY95 in order to replenish standby lines.

9. State and private banks and private corporates are assumed to borrow from the commercial markets $\$ 1.5$ billion and $\$ 2.5$ billion respectively in FY 1991 and those borrowings are assumed to increase at a GDP growth rate of $7.0 \%$ p.a. during the projection period.

10. In Annex IIIa, state enterprises (including Pertamina non recourse projects) are assumed to borrow \$1.5 billion in FY 1991 (excluding the Arun Aromatic project of \$1.4 billion) and \$0.6 billion each year in FY 1992 to FY 95.

11. In Annex IIlb, State enterprises (including Pertamina non recourse projects) are assumed to borrow $\$ 2.9$ billion in FY1991 (including Arun Aromatic project of $\$ 1.4$ billion) in FY 1991 and $\$ 4.0$ billion in each year during FY 1992 to FY 95.

12. Committed amounts by state enterprises are assumed to be disbursed over 3 years starting from the year of commitment. 


\title{
Document 12
}

\author{
THE COORDINATION OF MANAGEMENT OF OFFSHORE COMMERCIAL LOANS \\ (Presidential Decree No. 39/1991 dated September 4, 1991)
}

\begin{abstract}
THE PRESIDENT OF THE REPUBLIC OF INDONESIA,
Considering: $\quad$ a. that within the framework of implementing national development, coordinated policies and measures are needed for the management of offshore commercial loans;

b. that the utilisation of offshore commercial loans as a source of national development financing should be wisely managed to prevent pressure on the international balance of payments of Indonesia, avoid confusion in entering the international capital market and ensure offshore loan repayments being kept within limits of Indonesia's economic capacity;

c. that in order to carry out the said coordination of management of offshore commercial loans, it is deemed necessary to set up a team for the coordination of management of offshore commercial loans.
\end{abstract}

In view of:

To stipulate:

FIRSTLY:

SECONDLY:
Article 4 paragraph (1) of the Constitution of 1945.

\section{DE CIDES :}

THE PRESIDENTIAL DECREE CONCERNING THE COORDINATION OF MANAGEMENT OF OFFSHORE COMMERCIAL LOANS.

To set up the Team for the Coordination of Management of Offshore Commercial Loans, hereinafter referred to as the Team for Offshore Commercial Loans.

The Team for Offshore Commercial Loans shall be in charge of:

1. coordinating the management of all offshore commercial loans, namely all offshore loans outside the framework of the IGGI and other official loans needed by the government. state owned corporations (including state banks and Pertamina) and private companies (including banks and non-bank institutes of finance);

2. determining the total amount of offshore commercial loans to be procured from the international capital market in a fiscal year and laying down guidelines regarding the requirements for offshore commercial loans, with the aim of preventing any pressure on the international balance of payments of Indonesia and ensuring offshore loan repayments within limits of Indonesia's economic capacity;

3. determining the priority order of offshore commercial loans for financing development projects and offshore commercial loans for other purposes, on the condition that the entire amount does not exceed the total already fixed for the relevant fiscal year as meant in point 2;

4. fixing schedules for the procurement of loans on the international capital market for the respective loans already approved by the Team for Offshore Commercial Loans with the aim of avoiding confusion in entering the international capital market and securing favourable terms for the loans;

5. laying down methods and procedures for requesting approval for the procurement of offshore commercial loans as well as methods and procedures for periodical reporting by borrowers concerning the realisation and utilisation of offshore commercial loans; 
THIRDLY:

FOURTHLY:

In executing its duties the Team for Offshore Commercial Loans shall be responsible to the President.

FIFTHLY: In executing its duties the Team for Offshore Commercial Loans shall be allowed:

a. to use the services of experts needed;

b. to set up working groups for the handling of specific problems;

c. to request materials and information needed from ministries, non-departmental government agencies, state owned corporations and other parties;

SIXTHLY: $\quad$ The loans as referred to below shall belong to the types of loans subject to management coordination by the Team for Offshore Commercial Loans;

a. loans connected with development projects whose financing is of the nature of non-recourse loans, limited recourse loans, advance payments, trustee borrowings, leasing and so forth;

b. loans connected with development projects whose financing is based on BOT (build, operate and transfer), B\&T (build and transfer) and so forth.

SEVENTHLY: The loans as referred to below shall not belong to the types of loans subject to management coordination by the Team for Offshore Commercial Loans:

a. offshore commercial loans for trading needs of a short term nature;

b. offshore commercial loans procured by private companies for development project financing having nothing to do with the government or state owned corporations (including state banks and Pertamina) in the form of state capital participation, guarantee for basic material supply, guarantee for the purchase of products or linkage in whatever forms;

c. other offshore commercial loans as determined by the Team for Offshore Commercial Loans.

EIGHTHLY: Further details of the types, amounts and periods of the loans as meant in the Seventh dictum shall be determined by the Team for Offshore Commercial Loans. 
NINTHLY: $\quad$ Prospective borrowers shall submit applications to the Team for Offshore Commercial Loans to obtain approval for the procurement of offshore commercial loans, along with complete information on plans for their utilisation.

TENTHLY: $\quad$ Prospective borrowers shall not be justified to enter the international capital market for talks about the possibility of securing loans before obtaining decisions on schedules for the procurement of loans on the international capital market from the Team for Offshore Commercial Loans.

ELEVENTHLY: Excepted from the provisions in the Ninth and Tenth dictums shall be the types of loans as meant in the Seventh and Eighth dictums.

TWELFTHLY: All borrowers, including those mentioned in the Seventh and Eighth dictums, shall be obligated to submit periodical reports to the Team for Offshore Commercial Loans on the realisation of the offshore commercial loans they obtain.

THIRTEENTHLY: The procedure for the execution of the duties of the Team for Offshore Commercial Loans shall be stipulated by the Chairman of the Team for Offshore Commercial Loans.

FOURTEENTHLY: The cost for the execution of the duties of the Team for Offshore Commercial Loans shall be borne by Bank Indonesia.

FIFTEENTHLY: Matters which are not yet sufficiently regulated in and constitute the implementation of this presidential decree shall be stipulated by the Chairman of the Team for Offshore Commercial Loans.

SIXTEENTHLY: This presidential decree shall come into force as from the date of stipulation.

Stipulated in Jakarta

On September 4, 1991.

THE PRESIDENT OF THE REPUBLIC OF INDONESIA, sgd.

SOEHARTO. 